\title{
EMPLOYABILITY: Literatuurstudie naar theorie en empirie
}

Citation for published version (APA):

Mommers, A., Künn, A., \& van Eldert, P. (2017). EMPLOYABILITY: Literatuurstudie naar theorie en empirie. ROA. ROA Reports No. 002 https://doi.org/10.26481/umarep.2017002

Document status and date:

Published: 01/01/2017

DOI:

10.26481/umarep.2017002

Document Version:

Publisher's PDF, also known as Version of record

\section{Please check the document version of this publication:}

- A submitted manuscript is the version of the article upon submission and before peer-review. There can be important differences between the submitted version and the official published version of record.

People interested in the research are advised to contact the author for the final version of the publication, or visit the DOI to the publisher's website.

- The final author version and the galley proof are versions of the publication after peer review.

- The final published version features the final layout of the paper including the volume, issue and page numbers.

Link to publication

\footnotetext{
General rights rights.

- You may freely distribute the URL identifying the publication in the public portal. please follow below link for the End User Agreement:

www.umlib.nl/taverne-license

Take down policy

If you believe that this document breaches copyright please contact us at:

repository@maastrichtuniversity.nl

providing details and we will investigate your claim.
}

Copyright and moral rights for the publications made accessible in the public portal are retained by the authors and/or other copyright owners and it is a condition of accessing publications that users recognise and abide by the legal requirements associated with these

- Users may download and print one copy of any publication from the public portal for the purpose of private study or research.

- You may not further distribute the material or use it for any profit-making activity or commercial gain

If the publication is distributed under the terms of Article $25 \mathrm{fa}$ of the Dutch Copyright Act, indicated by the "Taverne" license above, 
Research Centre for Education and the Labour Market | ROA

\section{EMPLOYABILITY: Literatuurstudie naar theorie en empirie}

\section{ROA Rapport}

ROA-R-2017/2

Researchcentrum voor Onderwijs en Arbeidsmarkt | ROA Research Centre for Education and the Labour Market / ROA 


\section{EMPLOYABILITY: LITERATUURSTUDIE NAAR THEORIE EN EMPIRIE}

ROA-R-2017/2

Ardi Mommers

Annemarie Künn-Nelen

Peter van Eldert 


\section{Colofon}

(C) Researchcentrum voor Onderwijs en Arbeidsmarkt (ROA). Niets uit deze uitgave mag op enige manier worden verveelvoudigd zonder voorafgaande schriftelijke toestemming van de directeur van het ROA.

\section{Researchcentrum voor Onderwijs en Arbeidsmarkt}

School of Business and Economics

Maastricht University

email: secretary-roa-sbe@maastrichtuniversity.nl

website: www.roa.nl

\section{Vormgeving}

ROA secretariaat, Maastricht

ISBN: 978-90-5321-554-8

april 2017 


\section{INHOUD}

$\begin{array}{lr}\text { Voorwoord } & \text { i } \\ \text { English summary } & \text { iii } \\ \text { Samenvatting } & \text { vii }\end{array}$

01 Inleiding 1

$\begin{array}{ll}\text { 1.1 Hoger onderwijs en arbeidsmarkt } & 1\end{array}$

1.2 Onderzoeksvragen en -focus 2

1.3 Leeswijzer 3

02 Definities $\quad 5$

2.1 Verschillende invullingen $\quad 5$

03 Theoretische modellen 9

$\begin{array}{ll}3.1 & \text { Modellen }\end{array}$

3.2 Het 'key to employability-model' (Dacre Pool \& Sewell, 2007) 11

04 Het meten van 'employability' 19

4.1 'Objectieve' en 'subjectieve' maatstaven 19

4.2 Meetinstrumenten en de relatie met definities 21

4.3 Kritiekpunten bestaande meetinstrumenten 22

$\begin{array}{ll}4.4 & \text { Alternatief } \\ & 23\end{array}$

05 Determinanten 25

$\begin{array}{lll}5.1 & \text { Typologie van relevante factoren } & 25\end{array}$

\begin{tabular}{ll}
5.2 & Individuele factoren \\
\hline
\end{tabular}

5.3 Opleidings- en instellingsspecifieke factoren 26

$\begin{array}{lll}5.4 & \text { Arbeidsmarktfactoren } & 27\end{array}$

06 Het bevorderen van 'employability skills': empirie 29

\begin{tabular}{ll}
6.1 & 'Employability' en empirie \\
\hline
\end{tabular}

6.2 Nadruk op 'employability skills' (Cranmer, 2006) 29

6.3 Mason, Williams \& Cranmer (2009) 30

6.4 Career management skills (Bridgstock, 2009) 31

6.5 'Employability skills' ter compensatie (Wilton, 2011) 32

$\begin{array}{ll}\text { 6.6 Aanleren van 'employability skills' } & 33\end{array}$ 
07 Conclusies \& discussie

7.1 Conclusies

35

7.2 Discussie

38

Procedure raadplegen literatuur 41

Referenties 


\section{VOORWOORD}

De voor u liggende literatuurstudie maakt deel uit van een breder onderzoek naar de 'employability' van afgestudeerden van Maastricht University. Alvorens de 'employability'van deze specfieke groep afgestudeerden in kaart te brengen én de voorspellers van hun succes te analyseren heeft binnen het project een literatuurstudie plaatsgevonden. Dit rapport biedt een overzicht van de literatuur die ingaat op de meest gangbare theorieën van 'employability' alvorens een overzicht te geven van meetbare indicatoren en determinanten. Een belangrijke constatering is dat het concept 'employability' vele invullingen kent en er vele theoretische modellen over het concept zijn. Niettemin is het empirisch onderzoek naar de effectieve bijdrage van het hoger onderwijs aan de 'employability' van hun studenten schaars. Uit een handvol studies blijkt dat er geen duidelijke bevestiging wordt gevonden dat nadruk op 'employability skills' tijdens de opleiding invloed heeft op arbeidsmarktuitkomsten op korte termijn. Wel zijn er andere manieren waarop het onderwijs, naast het aanleren van vakspecifieke competenties, ook breder bij kunnen dragen aan de arbeidsmarktkansen van studenten. Zo zijn er op basis van de besproken studies goede aanwijzingen dat het aanbieden van stagemogelijkheden binnen de opleiding of het aanbieden van loopbaanoriëntatie-activiteiten wel degelijk nuttig kunnen zijn voor het vinden van werk.

Prof. Dr. Rolf van der Velden

Directeur ROA 



\section{ENGLISH SUMMARY}

\section{Background and target}

The Dutch education went through a big expansion during the twentieth century and democratised quickly. As a result, groups that were underprivileged before got more possibilities (to get high up) at the labour market. However, the labour market perspectives are not equal for all graduates, despite the fact that over the decades the demand for a highly educated workforce has increased. To a certain extent the increased accessibility to higher education has led to more competition among the highly educated. There are for example large differences with respect to 'labour market success' between university-programmes. Moreover, opportunities on the labour market differ depending on the economic situation.

In other words, there are differences between, and developments in, the degree of employability of graduates. Some graduates are more employable than others, even though they have the same educational background. Apparently, aspects other than educational background play a role as well. The following questions arise: what does employability mean? Of what elements does it consist? How can it be measured and can it be increased? In this report we focus specifically on the literature about employability related to higher education.

\section{Definitions}

Roughly, the definitions of employability can be ordered on a scale from 'very individualistic' to 'very contextual'. The more 'individual' approach it is not so much about the factual situation whether someone with a certain set of skills has or finds employment, but rather about whether someone owns a set of skills that normally is perceived as favourable. Opposite to this 'individualistic' approach the 'contextual' approach exists. In the most extreme form, one's employability is solely dependent on the labour market situation (i.e. conjuncture). In this approach, 'employability' is explicitly linked to finding employment. In other words, if there is more demand than supply on the labour market, each jobseeker is employable.

In practice the most common definitions of employability are mixed forms of these two extremes. Those definitions are usually concerned with the 'relative opportunities' of individuals on (a given situation of) the labour market, given their specific set of skills. Hence it is presumed that individual differences as well as contextual circumstances are 
influencing one's labour market opportunities. Depending on the specific definition, the focus can be more on the attainment of employment, on maintaining employment, on being satisfied with one's employment etcetera. In short, there is not just one definition of employability.

\section{Types of factors}

If we presume a mixed definition with both an individualistic and a contextual part, namely that employability of students/graduates is determined by individual characteristics as well as contextual features, we can roughly distinguish three factors that play a role in employability: individual factors, educational and institutional specific factors and labour market factors.

Individual factors can be specified to a seemingly unlimited number of relevant characteristics. Every theoretical or empirical model for employability looks at different aspects. The broadly-oriented 'the key to employability'-model (Dacre, Pool \& Sewell, 2007) distinguishes five core elements: Career development learning, Experience, Degree subject knowledge, understanding \& skills, Generic skills (often referred to as 'employability skills'; skills such as creativity, flexibility and eagerness to learn) and Emotional intelligence (being able to cope with one's own emotions and the emotions of others). These five elements all have something to do with one's qualities. However, Harvey (2001) states that employers do not only select based on the candidate's qualities, but also based on sentiment, prejudices and personal preferences.

To a great extent the educational- and institution-specific factors follow the line of the individual factors. For example, the decision for a specific education programme has consequences for the development of specific know-how and job-specific skills. However, the education (or the institution) also plays a direct role for the employability of graduates. Employers can have a preference for students from certain institutions, purely because these institutions have a 'good image' or 'strong reputation', even though this does not guarantee that the graduate is qualitatively strong him/herself.

Finally, labour market factors play an important role for the opportunities of graduates as well. The probability to get work, the type of work, the reward for work, all these aspects also depend on the specific labour market situation (either locally, regionally or nationally) at that specific moment in time. The local, regional and national economic situation are of great influence to the labour market perspectives of graduates.

\section{Measurable indicators}

Roughly two types of indicators to measure employability can be distinguished: objective and subjective indicators. The choice for the type of indicator depends on the chosen approach to employability. The objective indicators deal with 'hard' labour market outcomes. These indicators are related to finding employment, and if so, to job conditions and job tasks. 
Therefore, these objective indicators are especially applicable to the more 'contextual' approach of employability: they show how graduates perform on the labour market compared to each other, given the specific labour market situation. With subjective indicators the emphasis is on the assessment of personal competences that are considered useful on the labour market, often referred to as 'employability skills'. This concerns for example personality traits such as eagerness to learn and flexibility, but also more concrete competences such as teamwork, communication etcetera.

\section{'Employability skills' and education}

The degree to which study programmes and institutions put emphasis on the teaching of generic skills such as communication, teamwork, ICT- skills etcetera differs a lot. Because of this one could presume that the graduates from study programmes with a strong emphasis on these competences are more employable. However, strong empirical evidence for this hypothesis is not found in this literature study. This might be due though to a relatively short evaluation period used in these studies. One could also argue that all study programmes at least spend some attention on employability skills. So whereas these competences can be very useful on the labour market, significant effects cannot be found as all students acquire at least some of them.

Nevertheless, this literature review indicates that there are possible improvements on other fronts of the curriculum. We distinguish between three empirical based 'employability improving measures':

1. Provide students the opportunity to gain practical experience, for example by including external internships in the curriculum. This requires a sufficient level of networking between education and the labour market.

2. Involve employees in the process of developing the curriculum and in executing it in practice, for example by giving guest lectures.

3. Include career and labour market orientation in the curriculum. Invest in the knowledge about the labour market (what kind of occupational structure is in place and where are the opportunities) and the conventions on the labour market (how should one behave).

We need to be a little careful though. The amount of relevant empirical literature on the contribution of education to employability and the value of employability skills is limited, which is recognized by researches within this domain. Employability literature is often theoretical, which makes it hard to form any judgements about effectiveness and usefulness. It seems to be appropriate to study the phenomenon employability in the future more empirically. 



\section{SAMENVATTING}

\section{Achtergrond en doelstelling}

Het Nederlandse onderwijs heeft in de twintigste eeuw een grote expansie doorgemaakt en democratiseerde snel, waardoor groepen die voorheen 'kansarm' waren meer mogelijkheden kregen (om op te klimmen) op de arbeidsmarkt. De arbeidsmarktperspectieven zijn echter niet gelijk voor alle afgestudeerden, ondanks het feit dat er in de loop der decennia steeds meer vraag is gekomen naar een hoogopgeleide beroepsbevolking. De toegenomen toegankelijkheid van het hoger onderwijs heeft in zekere zin ook geleid tot een groeiende concurrentie onder hoogopgeleiden. Zo zijn er bijvoorbeeld grote verschillen in 'arbeidsmarktsucces' tussen universitaire opleidingen, en verschillen de arbeidsmarktkansen ook veranderen ook over de jaren heen naar gelang de conjunctuur.

Er zijn dus verschillen tussen en ontwikkelingen in de mate van 'inzetbaarheid' van afgestudeerden, ofwel de 'employability'. De ene afgestudeerde is meer 'employable' dan de ander, zelfs als zij over dezelfde opleidingsachtergrond beschikken. Blijkbaar spelen er dus meer aspecten een rol dan enkel de gevolgde opleiding. Vragen die hierbij echter rijzen zijn: wat wordt precies met de term 'employability' bedoeld; uit welke elementen bestaat het; hoe is het meetbaar en kan het vergroot worden? Aan de hand van deze literatuurstudie pogen we hier meer inzicht in te geven. We richten ons in deze rapportage op specifieke literatuur over 'employability' in relatie tot het hoger onderwijs.

\section{Definities}

Ruwweg zijn de definities van 'employability' te ordenen op een schaal van 'zeer individualistisch' tot 'zeer contextueel' georiënteerd. Bij de meer 'individualistische' invullingen gaat het niet zozeer om de feitelijke situatie of iemand met een bepaalde set eigenschappen ook daadwerkelijk werk vindt of heeft, maar of men over een set eigenschappen beschikt die normaliter aantrekkelijk worden beschouwd. Tegenover deze 'individualistische' benadering, staat de 'contextuele' benadering. In de meest extreme vorm van deze benadering is iemands 'employability' puur afhankelijk van de arbeidsmarktsituatie (oftewel de conjunctuur). 'Employability' wordt hier zeer expliciet gerelateerd aan het vinden of hebben van werk. Wanneer er op de arbeidsmarkt meer vraag is dan aanbod, zal in principe iedere werkzoekende 'employable' zijn. 
In de praktijk bestaan de meest gangbare definities van 'employability' uit 'mengvormen' van deze invullingen. In dergelijke definities gaat het vaak om de 'relatieve kansen' van individuen op de (conjunctuurgevoelige) arbeidsmarkt, gegeven hun specifieke set van eigenschappen. Hierin wordt dus zowel verondersteld dat individuele verschillen, alsook de context van invloed is op iemands arbeidsmarktkansen. Afhankelijk van de specifieke definitie kan de focus vooral liggen op het krijgen van werk, het behouden van werk, het tevreden zijn met werk, het mobiel kunnen zijn op de arbeidsmarkt enzovoorts. Kortom: er is géén standaarddefinitie van 'employability'.

\section{Type factoren}

Als we uitgaan van een tussenvorm van een individualistische en contextuele benadering, namelijk dat de'employability'van studenten/afgestudeerden zowel wordt bepaald door individuele eigenschappen alsook contextuele kenmerken, kunnen we ruwweg drie typen factoren onderscheiden die een rol spelen bij 'employability'. Individuele factoren, opleidings- en instellingsspecifieke factoren en arbeidsmarktfactoren.

Onder individuele factoren is een schier oneindig aantal relevante persoonskenmerken te onderscheiden. leder theoretisch of empirisch model van 'employability' neemt weer andere aspecten mee. Het breed georiënteerde 'The key to employability' model van Dacre Pool \& Sewell (2007) onderscheidt een vijftal kernelementen: Career development learning (kennis en zelfbewustzijn op het gebied van loopbaanontwikkeling); Experience (werk- en levenservaring); Degree subject knowledge, understanding \& skills (vakspecifieke kennis en vaardigheden); Generic skills (vaak ook 'employability' skills genoemd: generieke vaardigheden zoals creativiteit, flexibiliteit en leergierigheid) en Emotional intelligence (om kunnen gaan met de eigen emoties en met die van anderen). Deze vijf elementen hebben vooral te maken met iemands 'kwaliteiten'. Harvey (2001) stelt echter dat werkgevers niet alleen op kwaliteit selecteren, maar ook op gevoel, vooroordelen en persoonlijke voorkeuren.

Opleidings- en instellingsspecifieke factoren lopen grotendeels via de individuele factoren. Zo heeft de keuze voor een specifieke opleiding gevolgen voor de ontwikkeling van specifieke vakkennis en vakspecifieke vaardigheden. Echter speelt de opleiding (of de instelling) ook een directe rol bij de 'employability' van afgestudeerden. Zo kunnen werkgevers een voorkeur hebben voor studenten vanuit bepaalde instellingen, puur omdat deze een goed 'imago' of sterke'reputatie' hebben, terwijl dit geen garantie is dat de afgestudeerde zelf ook kwaliteit sterk is.

Tot slot spelen ook arbeidsmarktfactoren een belangrijke rol bij de kansen van afgestudeerden. De kans op werk, het type werk, de beloning voor het werk, al deze aspecten zijn mede-afhankelijk van de specifieke arbeidsmarktsituatie (zij het lokaal, regionaal of landelijk) op een bepaald moment. De lokale, regionale en landelijke conjunctuur zijn van grote invloed op de arbeidsmarktperspectieven van afgestudeerden. 


\section{Meetbare indicatoren}

Ruwweg zijn er twee typen indicatoren te onderscheiden om 'employability' te meten, objectieve indicatoren en subjectieve indicatoren. De keuze voor het type indicatoren, heeft te maken met de specifieke benadering van 'employability' die men hanteert. Bij de objectieve indicatoren gaat het om 'harde' arbeidsmarktuitkomsten. Deze indicatoren hebben te maken met het al dan niet vinden van werk, en indien men werk heeft met de arbeidsvoorwaarden en de functie-inhoudelijke aspecten.

Objectieve indicatoren zijn daarmee vooral toepasbaar op de meer 'contextuele' benadering: het geeft aan hoe afgestudeerden het op de arbeidsmarkt doen in verhouding tot elkaar, gegeven de specifieke arbeidsmarktsituatie. Bij 'subjectieve indicatoren' ligt de nadruk vooral op het beoordelen van persoonlijke competenties die nuttig geacht worden op de arbeidsmarkt, vaak ook wel 'employability skills' genoemd. Het gaat dan bijvoorbeeld om 'scores' op karakteristieken zoals leergierigheid of flexibiliteit, maar ook om meer concrete competenties zoals teamwork, communicatie en dergelijke.

\section{'Employability skills' en het onderwijs}

De mate waarin opleidingen en instellingen de nadruk leggen op het bijbrengen van algemene competenties zoals communiceren, samenwerken, ICT-vaardigheden enzovoorts verschilt sterk. Hierdoor zou verondersteld kunnen worden dat de 'employability' van afgestudeerden afkomstig van opleidingen met een sterke aandacht voor die competenties kansrijker zijn op de arbeidsmarkt. Sterke empirische onderbouwing hiervoor wordt in deze literatuurstudie echter niet gevonden, hoewel de empirische studies vaak alleen kijkend naar de kortetermijneffecten (kort na afstuderen). Ook kan geredeneerd worden dat álle opleidingen op zijn minst enige aandacht besteden aan 'employability skills'. Deze competenties kunnen immers wel degelijk waardevol zijn op de arbeidsmarkt, maar omdat alle studenten er in ieder geval iets van meekrijgen, zijn er geen duidelijke significante verschillen waarneembaar.

Wel zijn er goede aanwijzingen dat er op andere fronten binnen het curriculum winst te behalen valt. We onderscheiden hier drie empirisch onderbouwde 'employabilitybevorderende maatregelen':

1. Bied studenten de mogelijkheid om praktijk-/werkervaring op te doen, bijvoorbeeld door externe stages op te nemen in het programma. Dit vereist goede netwerken tussen onderwijs en werkveld.

2. Betrek werkgevers bij de ontwikkeling van het curriculum én bij de daadwerkelijke uitvoering van het onderwijs, bijvoorbeeld door gastdocenten in te zetten.

3. Maak loopbaan- en arbeidsmarktoriëntatie onderdeel van het curriculum. Investeer in kennis over de arbeidsmarkt (hoe ziet de beroepenstructuur er uit, waar liggen de kansen) en over de conventies op de arbeidsmarkt (hoe dient men zich te profileren/ gedragen).

Wel moet er een slag om de arm worden gehouden. De hoeveelheid empirische literatuur naar de bijdrage van het onderwijs aan 'employability' en naar de 'waarde' van 
'employability skills' is beperkt gebleken, hetgeen ook onderschreven wordt door de wetenschappers in dit vakgebied zelf. 'Employability' literatuur is vaak theoretisch van aard, waardoor uitspraken over 'effectiviteit' of 'nut' moeilijk te doen zijn. Het lijkt dan ook zinvol om het fenomeen 'employability' in de toekomst meer vanuit een empirische bril te bezien. 


\section{1 \\ INLEIDING}

\subsection{Hoger onderwijs en arbeidsmarkt}

Het Nederlandse onderwijs heeft in de twintigste eeuw een grote expansie doorgemaakt en democratiseerde snel. In de loop der jaren groeide het aandeel hogeropgeleiden gestaag, zowel onder mannen als vrouwen en zowel in de 'hogere' als de 'lagere' sociale milieus (o.a. Ganzeboom, 1997; Tolsma \& Wolbers, 2010). Ook in veel andere landen groeide het opleidingsniveau en egaliseerden onderwijskansen (o.a. Thomas, Wang \& Fan, 2001). Deze snelle onderwijsgroei heeft twee hoofddoelen gediend, aldus Wilton (2011). Ten eerste dient de onderwijsgroei de economie: door technologische ontwikkelingen worden er steeds meer kennis en vaardigheden vereist. Ten tweede dient het de burgers zelf: het hoger onderwijs is breder toegankelijk geworden, waardoor groepen die voorheen 'kansarm' waren aanzienlijk meer mogelijkheden hebben gekregen (om op te klimmen) op de arbeidsmarkt.

In dit licht kan het hoger onderwijs dus gezien worden als een 'leverancier' van hoogwaardige arbeidskrachten en als drijvende kracht voor een kenniseconomie: "investment in human capital and lifelong learning is the foundation for success in a global economy" (Thompson, 2004, p.2). Een perspectief dat in de loop van de eeuw steeds breder gedragen werd. Waar het volgen van hoger onderwijs van oudsher vooral beschouwd werd als vorm van culturele opvoeding en ontplooiing, speelt 'voorbereiding op de arbeidsmarkt' in de moderne visie op onderwijs een steeds belangrijkere rol (Salter \& Tapper, 1994).

Hoewel weinigen zullen redeneren dat het (hoger) onderwijs enkel een vehikel is om de arbeidsmarkt te dienen, is arbeidsmarktrelevantie anno 2017 op zijn minst 'stevig verankerd' in het educatiestelsel. Zo werd in 2009 de Commissie Doelmatigheid Hoger Onderwijs (CDHO) ingesteld. Deze commissie brengt aan de ministers van OCW en EZ advies uit over de macrodoelmatigheid van (nieuwe) opleidingen, waarbij de arbeidsmarktperspectieven van studenten een belangrijke rol spelen. Deze arbeidsmarktperspectieven zijn namelijk niet voor alle studenten gelijk, ondanks het feit dat er in de loop der decennia steeds meer vraag is gekomen naar een hoogopgeleide beroepsbevolking (Felstead et al., 2007). Het (door de onderwijsexpansie) groeiende aanbod hoogopgeleiden loopt immers niet altijd of voor iedereen in de pas met de groeiende vraag naar hoogopgeleide arbeidskrachten (Keep \& Mayhew, 2004). De toegenomen toegankelijkheid van het hoger onderwijs heeft daarmee weliswaar geleid tot een grotere gelijkheid 
in de maatschappij, maar in zekere zin ook tot een groeiende concurrentie onder hoogopgeleiden (Wilton, 2011).

Zo zijn er bijvoorbeeld grote verschillen in 'arbeidsmarktsucces' tussen universitaire opleidingen, zoals blijkt uit het recente rapport Academici op de arbeidsmarkt (VSNU, 2016), gebaseerd op de Nationale Alumni Enquête. Hieruit volgt dat afgestudeerden uit het HOOP-gebied' Taal \& Cultuur "er op veel punten ongunstiger voor staan dan afgestudeerden in de andere HOOP-gebieden". Zo ligt de werkloosheid in deze opleidingssector bijna twee keer zo hoog als gemiddeld (13\% t.o.v. 7\%), en hebben relatief veel afgestudeerden uit deze sector een baan onder universitair niveau. Vrij opvallende verschillen, zeker omdat werkgevers bij hun personeelswerving lang niet altijd een specifieke opleidingsrichting vereisen (Purcell \& Pitcher, 1996).

Arbeidsmarktkansen verschillen niet alleen tussen opleidingen, maar veranderen ook over de jaren heen. Zo fluctueerde de werkloosheid onder pas afgestudeerden wo'ers in de periode 2009-2015 tussen de $5 \%$ en $10 \%$. Ook op het niveau van HOOP-gebieden zijn er grote verschillen over de tijd waarneembaar. Zo steeg het werkloosheidspercentage onder afgestudeerden uit de HOOP-gebieden Gezondheidszorg, Natuur en Taal \& Cultuur in de betreffende periode fors, terwijl de werkloosheid voor afgestudeerden uit het gebied Techniek juist afnam.

\subsection{Onderzoeksvragen en -focus}

De grote verschillen in de arbeidsmarktperspectieven van (universitaire) opleidingen enerzijds en de veranderlijkheid over de tijd anderzijds toont aan dat afgestudeerden met een bepaalde achtergrond op een bepaald tijdstip méér of mínder aantrekkelijk zijn voor de arbeidsmarkt. Er zijn derhalve verschillen tussen en ontwikkelingen in de mate van 'inzetbaarheid' van afgestudeerden, ofwel de 'employability'. Informatie over die mate van 'employability' zijn onder meer voor studiekiezers en onderwijsinstellingen relevant. Verschillen in arbeidsmarktsucces worden namelijk vaak gezien als een indicator voor de mate waarin instellingen studentcompetenties meer of minder weten te ontwikkelen (Mason, Williams \& Cranmer, 2009). Arbeidsmarktindicatoren worden dan ook vaak benut om kwaliteits- of employabilityrankings op te stellen over instellingen (bijvoorbeeld de internationale Graduate Employability Rankings).

'Employability' is een term die volop gebezigd wordt als het gaat om de perspectieven op de arbeidsmarkt, de ene afgestudeerde is meer'employable' dan de ander. Zelfs als zij over dezelfde opleidingsachtergrond beschikken. Blijkbaar spelen er dus meer aspecten een rol dan enkel de gevolgde opleiding. Vragen die hierbij dan ook onmiddellijk rijzen zijn: wat wordt precies met de term 'employability' bedoeld; uit welke elementen bestaat het; hoe is het meetbaar en kan het vergroot worden? Deze vragen staan in voorlig-

1 "De indeling (ook wel: CROHO-indeling) die door o.a. VSNU en ministerie OCW wordt gebruikt om onderwijssectoren te beschrijven" (VSNU, 2016) 
gende literatuurstudie centraal en worden aan de hand van de volgende onderzoeksvragen in kaart gebracht:

1. Welke definities van het concept 'employability' kunnen onderscheiden worden?

2. Welke (type) factoren vormen of beïnvloeden de 'employability' van individuen?

3. Welke (meetbare) indicatoren van 'employability' kunnen onderscheiden worden?

4. Hoe kan de 'employability' van individuen vergroot worden, in hoeverre bestaat hier empirische onderbouwing voor?

'Employability' gaat niet alleen om de initiële transitie van opleiding naar werk, immers is het belangrijk dat iemand ook in zijn verdere loopbaan aantrekkelijk is en blijft voor werkgevers. Een 'leven lang leren' is dan ook één van de speerpunten van de ministeries van OCW en SZW. In een continu veranderende arbeidsmarkt (zowel technologischorganisatorisch als qua personeelsopbouw) is het niet alleen belangrijk om een goede basisopleiding te hebben, maar ook om tijdens de loopbaan te blijven investeren in scholing (Borghans et al., 2014). Het fenomeen 'employability' kan dus breed beschouwd worden en de hoeveelheid 'employability' literatuur is dan ook bijzonder uitgebreid. Om overzicht en focus te behouden, zullen we ons in deze rapportage richten op specifieke literatuur over 'employability' in relatie tot het hoger onderwijs'2. Ook binnen deze afbakening is het onmogelijk om een uitputtend overzicht te geven van de voorradige literatuur. Voorliggende studie dient dan ook beschouwd te worden als een literatuuroverzicht op hoofdlijnen, opgebouwd rondom een aantal kernreferenties. We beogen hiermee structuur aan te brengen in de grote hoeveelheid literatuur, en een globaal inzicht te geven in de belangrijkste aspecten rond het fenomeen 'employability' in relatie tot het hoger onderwijs.

\subsection{Leeswijzer}

De opbouw van het rapport is als volgt. In hoofdstuk 2 gaan we in op diverse invullingen van het concept 'employability, we laten verschillende definities de revue passeren en bespreken we de kritieken die op de verschillende interpretaties bestaan. In hoofdstuk 3 bespreken we diverse modelleringen van 'employability', het gaat hier om de onderliggende elementen die personen meer of minder 'employable' kunnen maken. We gaan uitgebreid in op het model 'The key to employability' van Dacre Pool \& Sewell (2007). Hoofstuk 4 behandelt diverse instrumenten om 'employability' te meten, waarbij ingegaan wordt op het verschil tussen 'objectieve' maten en 'subjectieve' maten. In hoofdstuk 5 worden verschillende typen determinanten van 'employability' besproken op het niveau van het individu, de opleiding en/of de onderwijsinstelling en de arbeidsmarkt. In hoofdstuk 6 bespreken we een aantal empirische studies naar de bijdrage van het onderwijs aan 'employability' skills en de meerwaarde van deze vaardigheden op de arbeidsmarkt. Tevens worden enkele voorbeelden gegeven van manieren om de ontwikkeling van 'employability skills' te incorporeren in het onderwijs. In hoofdstuk 7

2 Een toelichting op de gehanteerde onderzoeksaanpak is terug te vinden in de bijlage. 
trekken we op basis van de voorgaande hoofdstukken de belangrijkste conclusies over 'employability' en het hoger onderwijs, en kaarten een discussiepunt aan. 


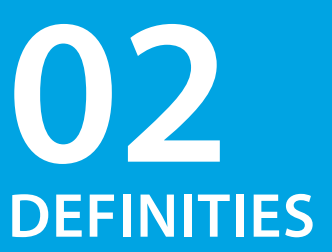

\subsection{Verschillende invullingen}

Het concept 'employability' kent vele invullingen (o.a. Lees, 2002; Yorke, 2006). Eén van de meest basale verschillen tussen de definities heeft betrekking op de focus op ofwel het specifieke individu, ofwel op het individu in relatie tot de context. Ook wel 'smalle' of 'brede' definities genoemd (o.a. Andrews \& Higson, 2008; Bridgstock, 2009). In dit hoofdstuk laten we enkele invullingen de revue passeren en bespreken we de kritieken die op de verschillende invullingen bestaan.

Eén van de populairste invulling van het concept (dat wil zeggen, waar veelvuldig naar gerefereerd wordt) betreft die van Hillage \& Pollard (1998). Zij redeneren in hun literatuurstudie dat, hoewel er geen standaarddefinitie van 'employability' bestaat, veel interpretaties een bepaalde gemeenschappelijke kern hebben die uit de volgende aspecten bestaat (p.2):

Employability is about work and the ability to be employed; i.e.

- the ability to gain initial employment; hence the interest in ensuring that 'key skills', carers advice and an understanding about the world of work are embedded in the education system;

- the ability to maintain employment and made 'transitions' between jobs and roles within the same organisation to meet new job requirements; and

- the ability to obtain new employment if required, i.e. to be independent in the labour market by being willing and able to manage their own employment transitions between and within organisations.

It is also, ideally, about

- the quality of such work or employment. People may be able to obtain work but it may be below their level of skill, or in low paid, undesirable or unsustainable jobs.

'Employability' betekent volgens Hillage \& Pollard in de meest eenvoudige zin van het woord dus het vermogen om bevredigend werk te vinden en te behouden, of zoals de auteurs het concept meer uitvoerig omschrijven: "employability is the capability to move 
self-sufficiently within the labour market to realise potential through sustainable employment." Vrij vertaald: 'het zelfredzaam binnen de arbeidsmarkt kunnen bewegen, om via duurzaam werk het eigen potentieel te realiseren'.

De definitie van Hillage \& Pollard is één van de meest gehanteerde interpretaties van 'employability'. Toch worden er ook kanttekeningen bij gezet. Zo stellen Brown, Hesketh \& Williams (2003) dat de definitie van Hillage \& Pollard 'ideologisch geladen' is. Het negeert het feit dat 'employability' voornamelijk bepaald wordt door de arbeidsmarkt, eerder dan door de capaciteiten van individuen. Brown et al. noemen als voorbeeld: wanneer dertig afgestudeerde hersenchirurgen solliciteren op tien vacatures, zullen er twintig geen baan krijgen. Volgens de definitie van Hillage \& Pollard zijn deze twintig dan niet 'employable' gebleken, omdat ze niet hebben aangetoond over het vermogen om 'initieel werk te vinden' te beschikken. Brown et al. verwerpen dit idee van 'blaming the victim', oftewel de schuld leggen bij degenen die geen werk kunnen vinden. De auteurs redeneren dat 'employability' varieert naar gelang de economische omstandigheden: ten tijde van arbeidstekorten zullen de werklozen 'employable' worden en ten tijde van arbeidsoverschotten zullen weer meer mensen 'unemployable' zijn. 'Employability' dient volgens hen daarom niet zozeer gedefinieerd te worden in termen van individuele eigenschappen, maar vooral in termen van: de relatieve kansen op het verkrijgen en behouden van werk gezien de arbeidsmarktcontext.

De kritiek van Brown et al. geeft volgens Yorke (2006) weer hoe complex het concept 'employability' is en hoeveel verschillende interpretaties er bestaan. Volgens Yorke interpreteren Brown et al. 'employability' als 'employment', doordat Hillage \& Pollard in hun definitie van het concept het ambigue woord 'capability' (vermogen) gebruiken. 'Capability' kan volgens Yorke enerzijds geïnterpreteerd worden als: 'het potentieel' of 'de noodzakelijke eigenschappen', maar anderzijds als: 'het (daadwerkelijk) vinden van werk'. Waar Brown et al. de aandacht vooral richten op de tweede, vooral arbeidsmarktgerelateerde invulling, en Hillage \& Pollard beide invullingen lijken te incorporeren, geeft Yorke aan zelf juist (vooral) naar de eerste, meer individuele invulling te neigen. Zijn omschrijving van 'employability' luidt: "a set of achievements - skills, understandings and personal attributes - that makes graduates more likely to gain employment and be successful in their chosen occupations, which benefits themselves, the workforce, the community and the economy." Waar Hillage \& Pollard een prettige, bevredigende baan dus vooral als 'ideaal' beschouwen (het gaat vooral om het vinden van werk), is dit voor Yorke, een kernaspect van 'employability'.

Hoewel Yorke in zijn definitie vooral de nadruk legt op het 'individuele aspect', vinden we ook in deze definitie een combinatie van 'employability' in termen van 'individuele eigenschappen' alsook in termen van het meer arbeidsmarkt-contextuele 'vinden van (bevredigend) werk'. Het één kan dus moeilijk, of zelfs niet, los worden gezien van het ander. Zonder het benodigde 'individuele potentieel' zal men niet of nauwelijks aan werk kunnen komen en/of blijven, maar het niet (direct) kunnen vinden van werk maakt iemand niet per definitie 'unemployable'. Yorke is het dan ook nadrukkelijk eens met 
Brown et al. als het gaat over de contextgevoeligheid van 'employability', zo zegt hij over zijn definitie: "It is probabilistic. There is no certainty that the possession of a range of desirable characteristics will convert employability into employment: there are too many extraneous socio-economic variables for that (e.g. national, regional and/or local economic health, and the demand/supply ratio for the characteristics in question)." 



\section{3 \\ THEORETISCHE MODELLEN}

\subsection{Modellen}

Zoveel definities van 'wat employability is', zoveel uiteenzettingen zijn er van 'waar employability uit bestaat'. In de basis lijkt er behoorlijke eenduidigheid over het feit dat 'employability' in ieder geval iets te maken heeft met 'voor de arbeidsmarkt relevante eigenschappen'. De invullingen en modelleringen van deze typen eigenschappen lopen echter volop uiteen. De mate van detaillering verschilt bijvoorbeeld in zeer sterke mate. Zo destilleert Jackson (2010) uit haar uitgebreide literatuurstudie maar liefst 41 verschillende aspecten van 'employability', van technologische vaardigheden, tot levenservaring tot ondernemerschap tot creativiteit. Om de ontleding van het concept'employability' in dit literatuuroverzicht zo overzichtelijk en handzaam mogelijk te houden, richten we ons in dit hoofdstuk op een aantal veelgebruikte modellen die het concept zo kernachtig mogelijk uiteen zetten.

Volgens Hillage \& Pollard (1998) bestaat 'employability' uit vier hoofdelementen. Allereerst gaat het om de 'employability assets', oftewel nuttige eigenschappen waarover men beschikt. Deze 'assets' bestaan uit 'kennis', 'vaardigheden' en 'attitudes.' Het tweede element betreft 'deployment', het gaat dan om de inzet van wat de auteurs noemen 'managementvaardigheden', waaronder onder meer 'job search skills' worden geschaard. Het derde element 'presentation' gaat over de vaardigheden om banen te kunnen verkrijgen, zoals het beschikken over werkervaring, het kunnen opstellen van een goed cv, en het kunnen presenteren van goede sollicitatietechnieken. Hun vierde element van 'employability' heeft vooral betrekking op de contextuele omstandigheden. Om individuele 'assets' (optimaal) in te kunnen zetten, is men afhankelijk van persoonlijke omstandigheden (bijvoorbeeld verantwoordelijkheden voor het gezin) en externe factoren (zoals het actuele 'kansniveau' op de arbeidsmarkt).

Eén van de bekendste en meest gerespecteerde 'employability'-modellen, aldus Dacre Pool \& Sewell (2007), betreft het USEM-model van Knight \& Yorke (o.a. 2002). USEM is een afkorting van vier onderling gerelateerde componenten van 'employability': 'Understanding', 'Skills', 'Efficacy beliefs' en 'Metacognition'. Knight \& Yorke redeneren dat er in de curricula binnen het hoger onderwijs vooral aandacht wordt besteed aan kennis en begrip ('understanding'), alsook aan vakspecifieke en generieke vaardigheden 
('skills'), maar nauwelijks aan 'efficacy beliefs' en 'metacognitie' Ze stellen: “Curricula seem typically to pay little attention to personal qualities or to focus on moral and quasi-moral qualities that practitioners need to display in professions with a primary care for people and their needs. They are mainly silent on self-theories and efficacy beliefs." Dit terwijl klachten over de transitie van opleiding naar werk volgens Cappelli (1995) zelden over een gebrek aan academische vaardigheden gaan, maar vooral over tekorten aan geschikte 'work attitudes', vooral op het gebied van 'persoonlijkheid' (zoals het accepteren van gezag) en 'motivatie' (zoals het nemen van initiatieven). Ook Feinstein (2000) toont aan dat 'psychologische en gedragsattitudes' belangrijk zijn voor de kansen op de arbeidsmarkt. Zo hebben jongeren met een kleinere aandachtsspanne of gedragsproblemen bijvoorbeeld een grotere kans op werkloosheid. In het USEM-model hebben deze psychologische inzichten dan ook een belangrijke positie, USEM laat zich als volgt visualiseren (Figuur 3.1).

FIGUUR 3.1 USEM model of employability (Knight \& Yorke, 2002, p.265)

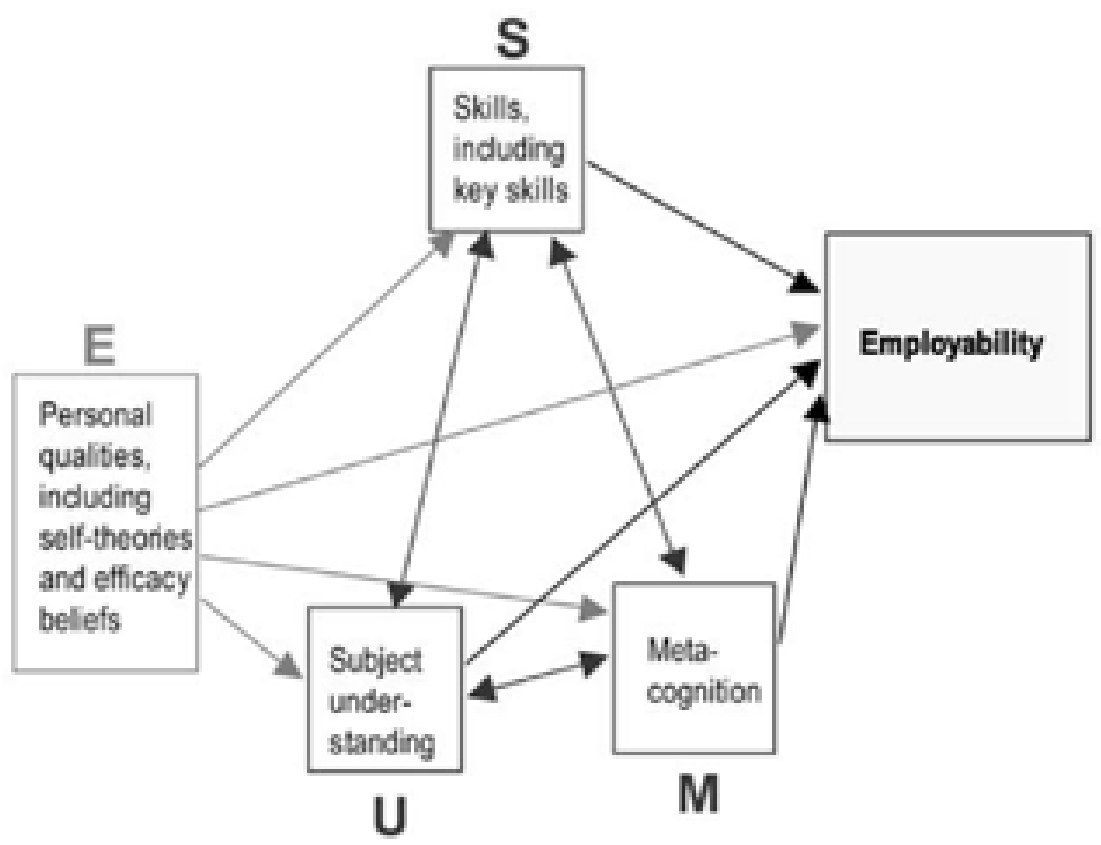

Het model is zoals gestoeld op wetenschappelijke theorieën en onderbouwde bewijsvoering, maar is volgens Dacre Pool \& Sewell (2007) juist door deze academische grondslag te abstract van aard: "it does not assist in explaining to non-experts in the field, particularly the students themselves and their parents, exactly what is meant by employability." (p.281). Een meer concrete invulling van 'employability' die gezien de meer praktische invalshoek veelvuldig benut wordt binnen de 'career planning education' (Pegg et al, 
2012) betreft het zogenaamde DOTS-model van Law \& Wats (1977). Dit model gaat uit van (Watts, 2006, pp.9-10):

Planned experiences designed to facilitate the development of:

- Decision learning - decision making skills

- Opportunity awareness - knowing what work opportunities exist and what their requirements are

- Transition learning - including job searching and self presenting skills

- Self awareness - in terms of interests, abilities, values, etc."

Het DOTS-model is zoals gezegd wat minder abstract en geeft eenvoudiger weer welke eigenschappen studenten dienen te ontwikkelen om hun 'employability' te vergroten. Kort gezegd heeft DOTS betrekking op het leren maken van beslissingen ('decision learning'), het ontwikkelen van bewustzijn over welke arbeidsmarktkansen er bestaan en wat er wordt gevraagd liggen ('opportunity awareness'), het leren om de overstap naar de arbeidsmarkt te kunnen maken ('transition learning'), en het ontplooien van zelfbewustzijn op het gebied van interesses, capaciteiten en dergelijke.

\subsection{Het 'key to employability-model' (Dacre Pool \& Sewell, 2007)}

Een belangrijke tekortkoming van het DOTS-model is volgens Dacre Pool \& Sewell (2007) echter dat het geen rekening houdt met het element 'tevredenheid'. Volgens deze auteurs gaat'employability' niet alleen om "having a set of skills, knowledge, understanding and personal attributes that make a person more likely to choose and secure occupations" maar ook om "...in which they can be satisfied and successful." Dacre Pool \& Sewell nemen deze definitie als uitgangspunt van 'employability' en bouwen vanuit dit uitgangspunt hun zogenaamde 'The key to employability model' op. Dit model kan gezien worden als een meta-model van diverse eerdere 'employability'-modellen. Het geeft daarmee een geïntegreerd beeld van verschillende relevante modellen en inzichten (o.a. Bennett, Dunne \& Carré, 1999; Knight \& Yorke, 2004; Watts, 2006) en leent zich dan ook goed voor voorliggende literatuurstudie. Het model gaat ervan uit dat ieder element van belang is en dat het ontbrekend van een bepaald element grote gevolgen heeft voor iemands 'employability'. In Figuur 3.2 is het model grafisch weergegeven. 


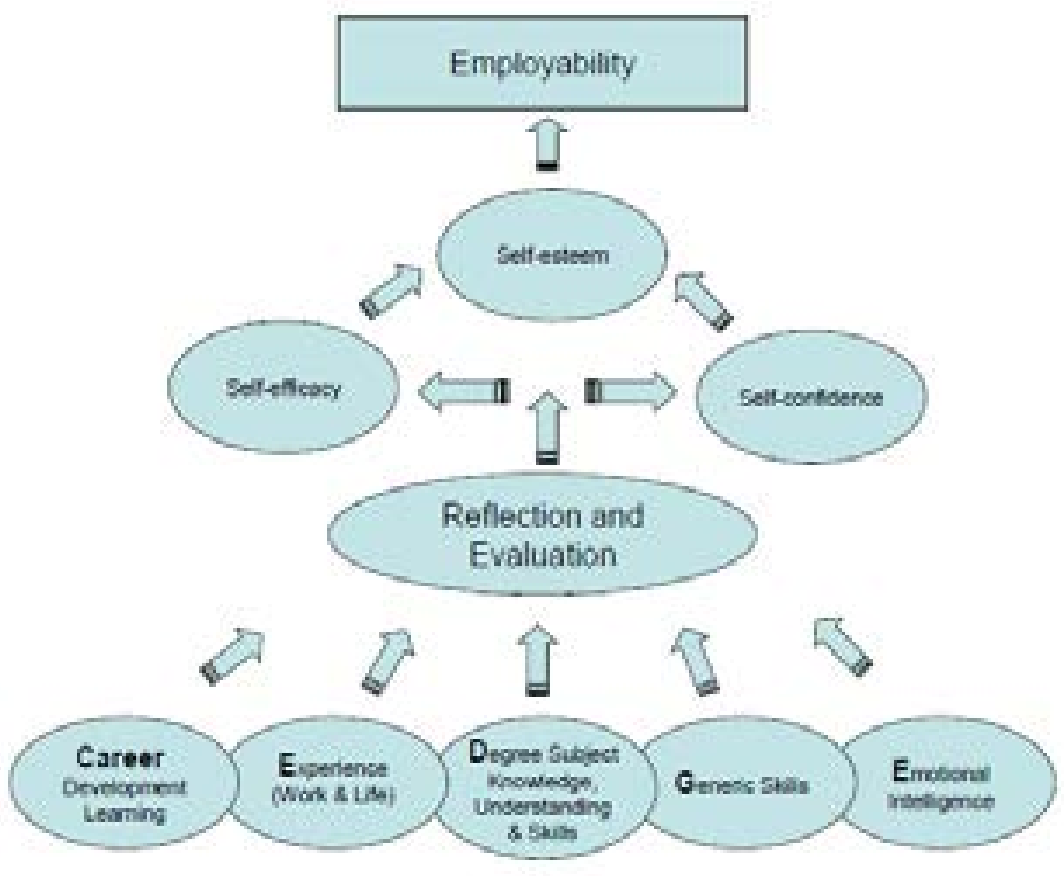

Aan de basis van het model staan vijf typen eigenschappen die studenten dienen te ontwikkelen en waar ze 'toegang' tot dienen te hebben: 'career development learning', 'experience', 'degree subject knowledge, understanding \& skills', 'generic skills' en 'emotional intelligence'. De auteurs noemen dit gezamenlijk 'CareerEDGE', een combinatie van 'career development learning' en de beginletters van de andere vier eigenschappen. Het reflecteren over en evalueren van deze 'CareeerEDGE'-eigenschappen leidt volgens het model tot een bepaalde mate van 'self-efficacy', 'self-esteem' en 'self-confidence', hetgeen vervolgens de cruciale verbinding is met 'employability'. We bespreken de verschillende elementen uit model hier kort:

\subsubsection{CareerEDGE}

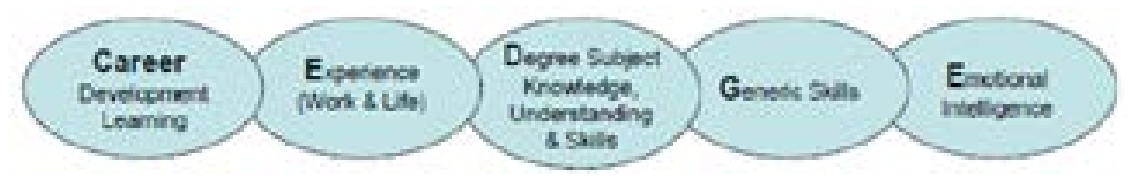




\section{Career development learning}

Om banen te vinden en te behouden waarin men tevreden en succesvol is, is het volgens Dacre Pool \& Sewell noodzakelijk dat studenten grip krijgen op het concept 'loopbaanontwikkeling'. Het gaat dan onder meer om het creëren van zelfbewustzijn zoals: 'wat vind ik leuk en interessant' en 'wat motiveert mij', maar ook om het verkrijgen van inzicht over de relatie van de persoon tot de arbeidsmarkt: 'waar liggen mijn kansen', 'hoe presenteer ik mijzelf', 'hoe kan ik goede carrièrebeslissingen' maken enzovoorts. 'Career development learning' richt zich op de gehele beroepsloopbaan, het gaat dus niet alleen over de initiële stap van opleiding naar de arbeidsmarkt, maar ook over duurzame carrièreontwikkeling. 'Employability' gaat (o.a. volgens Hillage \& Pollard, 1998) idealiter immers niet alleen om het verkrijgen van een baan, maar ook om het behouden van een blijvend aantrekkelijke baan, dan wel om het geoutilleerd zijn om naar een beter passende baan over te stappen.

\section{Experience (work \& life)}

Afgestudeerden die de arbeidsmarkt betreden zijn zelden volledig 'nieuw' op de arbeidsmarkt. Dat wil zeggen: zij hebben vaak al in meer of mindere mate ervaring opgedaan in bijbanen, stages en dergelijke. Anderen zijn pas op latere leeftijd (verder) gaan studeren, bijvoorbeeld om door te kunnen groeien in betere banen. Ook de mate van 'levenservaring' in brede zin verschilt van afgestudeerde tot afgestudeerde. Hoewel de transitie van opleiding naar werk vaak beschouwd wordt als het betreden van een nieuwe wereld, is dit in de praktijk vaak niet (echt) het geval. Ervaring blijkt, óók voor pas afgestudeerden, uit de empirie dan ook een relevante factor op de arbeidsmarkt. Light (2001) toont in haar Amerikaanse onderzoek bijvoorbeeld aan dat de lonen na afstuderen hoger liggen als men tijdens studie werkervaring heeft opgedaan. Volgens Dacre Pool \& Sewell ligt er dan ook een taak voor hogeronderwijsinstellingen om studenten hierop attent te maken. Het stimuleren van het opdoen van werkervaring, bijvoorbeeld door stages te faciliteren of bijbanen toe te juichen, lijkt derhalve zinvol (mits dit het leerproces niet negatief beïnvloedt).

\section{Degree subject knowledge, understanding \& skills}

Werkgevers beoordelen afgestudeerden onder meer op hun prestaties tijdens hun opleiding, bijvoorbeeld aan de hand van afstudeercijfers. Voor werkgevers is dit vaak ook de enige 'harde' maatstaf waarlangs zij afgestudeerden kunnen leggen. Dit geldt in zeer sterke mate voor banen waarbij vakspecifieke kennis en vaardigheden ('degree subject knowledge, understanding \& skills') benodigd zijn, bijvoorbeeld in de ICT-sector (Yorke, 2006). Sollicitanten dienen aan te kunnen tonen dat zij over deze vakcompetenties beschikken.

Vakcompetenties zijn echter ook belangrijk zijn voor banen waarbij deze specifieke competenties inhoudelijk eigenlijk niet essentieel zijn. Ook hier zijn de (vakspecifieke) prestaties van studenten volgens Dacre Pool \& Sewell voor werkgevers dé belangrijkste maatstaf waarop sollicitanten vergeleken kunnen worden. Vakspecifieke kennis en vaardigheden zijn derhalve zeer belangrijk voor iemands 'employability'. Maar: ze zijn 
op zichzelf nog niet voldoende om een baan te verkrijgen, te behouden en deze ook succesvol en naar eigen tevredenheid in te kunnen vullen. Het draait om de combinatie van eigenschappen.

\section{Generic skills}

Onder algemene vaardigheden ('generic skills', ook wel: kernvaardigheden of sleutelvaardigheden) verstaan Dacre Pool \& Sewell, conform de definitie van Bennett, Dunne \& Carré (1999, p.76): "skills which can support study in any discipline, and which can potentially be transferred to a range of contexts, in higher education or the workplace." Het gaat dus om generieke vaardigheden die men in een breed scala aan situaties kan inzetten. Het is dit type vaardigheden waar werkgevers, naast vakspecifieke competenties, grote behoefte aan hebben. Het gaat dan bijvoorbeeld om vaardigheden als creativiteit, flexibiliteit, leergierigheid, autonomie en teamwork. In die behoefte wordt echter lang niet altijd voorzien en wordt soms als tekortkoming van het hoger onderwijs beschouwd, zo stelt Yorke (2006): "Whereas the world of employment has, by and large, been satisfied with the disciplinary understanding and skills developed as a consequence of participation in higher education, it has been less happy with the development of what have been termed 'generic skills'"' (p.4).

Vakspecifieke kennis en vaardigheden zijn weliswaar nog altijd nodig op de arbeidsmarkt, maar worden volgens Brown et al. (2003) steeds meer als 'vanzelfsprekendheid' gezien. Zo geeft een HR-manager in hun kwalitatieve studie aan: "Academic qualifications are the first tick in the box and then we move on. Today we simply take them for granted." (p.120). Een minimumniveau van vakcompetenties wordt weliswaar vereist "for [some] employers, a general 'graduatenes' [...] appears to be deemed sufficient" (Yorke, 2006, p.4) - maar juist de generieke competenties zijn dé onderscheidende factoren bij het wervingsproces (Brown et al., 2003). Het belang van dergelijke competenties wordt ook door het hoger onderwijs onderschreven, en blijkt onder meer uit de Europese Dublin-descriptoren (NVAO, 2004). Dit betreffen algemene eindtermen voor universitaire studies waarin naast academische kennis ook nadrukkelijk aandacht is voor generieke competenties zoals communicatie en oordeelsvorming.

'Generic skills' zijn uiteenlopend van aard, en kunnen ze net zo goed betrekking hebben op fysieke aspecten (zoals de inzet van lichaamstaal bij communicatie), als op mentale aspecten (zoals analytisch inzicht en logisch redeneren). Weer andere eigenschappen die soms als 'algemene vaardigheden' worden betiteld, zijn strikt genomen geen vaardigheden als wel 'attitudes' zoals waarden en normen. Sommige 'vaardigheden' kunnen ontwikkeld worden door onderwijs en oefening, terwijl andere vooral een product zijn van sociaal-culturele omstandigheden. (Hager, Holland \& Beckett, 2002).

\section{Emotional intelligence}

Hoewel emotionele intelligentie gezien de voorgaande omschrijvingen beschouwd kan worden als één van de 'algemene vaardigheden', positioneren Dacre Pool \& Sewell deze eigenschap bewust als afzonderlijk component van 'employability'. Emotionele 
intelligentie is volgens hen namelijk één van de meest essentiële elementen voor 'employability'. De auteurs hanteren Golemans definitie van emotionele intelligentie: "the capacity for recognising our own feelings and those of others, for motivating ourselves, and for managing emotions well in ourselves and in our relationships." (1998, p.317). Cooper (1997) stelt dat mensen met hoge emotionele intelligentie succesvoller zijn in hun carrière, effectievere leiders zijn en sterkere persoonsbanden ontwikkelen. Emotionele intelligentie kan volgens Tucker et al. (2000), ontwikkeld en (deels) aangeleerd worden en dient volgens de auteurs dan ook onderdeel uit te maken van het curriculum in het hoger onderwijs.

\subsubsection{Reflectie en evaluatie en de 'drie S'en'}

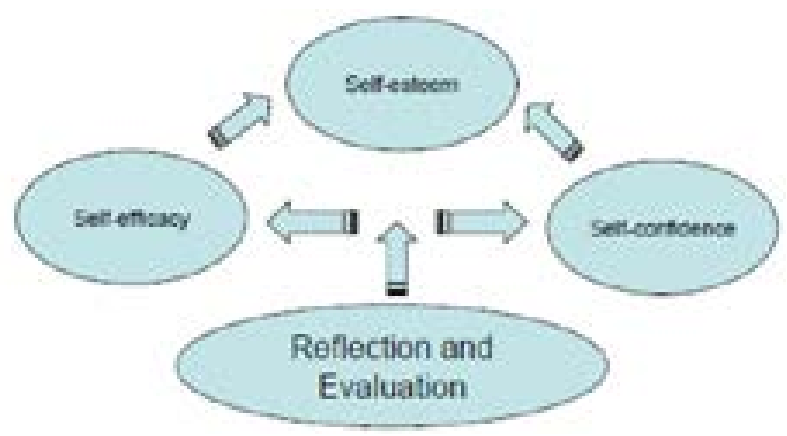

\section{Reflectie en evaluatie}

Het voorzien van studenten met de benodigde vaardigheden, kennis, begrip en overige eigenschappen staat aan de basis van het 'key to employability model', maar zeker zo belangrijk is volgens Dacre Pool \& Sewell het 'reflecteren en evalueren' van die eigenschappen. Als een student zijn eigen eigenschappen niet goed kan inschatten, bijvoorbeeld wat het eigen niveau van kennis en vaardigheden is, kan deze zich ook niet 'optimaal' positioneren op de arbeidsmarkt. Ook is een goede zelfreflectie essentieel om te kunnen beoordelen waar het nog 'aan schort' en op welke manier iemand zijn positie kan versterken. Via deze reflectie en evaluatie ontwikkelt de student een bepaalde mate van 'self-efficacy', 'self-confidence' en 'self-esteem' (de 'drie S'en') die iemands 'employability' bepalen, waarover zo meer. Hoewel iemand niet zozeer kan worden 'aangezet' om te reflecteren, kan het hoger onderwijs volgens Moon (2004) wel bijdragen aan de ontwikkeling van het reflectief en evaluerend vermogen. Het gaat dan bijvoorbeeld om het gebruik van persoonlijke ontwikkelingsplannen (POP) en leerdagboeken, maar ook om praktijkgerelateerd onderwijs waarin studenten hun opgedane kennis en vaardigheden concreet toe moeten passen. Dit kan bijdragen aan een betere zelfreflectie over waar men staat en wat verder ontplooid moet worden. 


\section{Self-efficacy}

De onderling gerelateerde concepten 'self-efficacy', 'self-confidence' en 'self-esteem', ruwweg vertaalbaar als 'zelfeffectiviteit', 'zelfvertrouwen' en (binnen deze context) 'zelfbewustzijn' spelen in het model van Dacre Pool \& Sewell een cruciale verbinding tussen kennis, vaardigheden, ervaring en persoonlijke eigenschappen enerzijds en 'employability' anderzijds. De ingeschatte 'self-efficacy' refereert volgens de opsteller van de zelfeffectiviteitstheorie Bandura (1995, p.2) naar: "beliefs in one's capabilities to organize and execute the course of action required to manage prospective situations. Efficacy beliefs influence how people think, feel, motivate themselves and act." Zelfeffectiviteit heeft dus ruwweg te maken met het geloof dat men heeft over het succesvol kunnen uitoefenen van bepaalde taken. Naarmate de zelfeffectiviteit hoger wordt ingeschat, neemt de 'employability' ook toe, zo stellen Dacre Pool \& Sewell (2007, p.95): "A graduate who believes they can do whatever is necessary is far more likely to gain a position and be successful in whatever occupations they choose than a graduate who does not have that self-belief." De 'beliefs' worden volgens Bandura onder meer gevormd door (reflectie en evaluatie van) 'mastery experiences,' 'vicarious experiences' en 'social persuasion'.

De 'mastery experiences' of 'meesterschap-ervaringen' spelen een centrale rol voor 'selfefficacy' en ontstaan wanneer iemand de kans krijgt om een bepaalde taak uit te voeren. In relatie tot'employability' in het hoger onderwijs kan dan bijvoorbeeld gedacht worden aan het opdoen van werkervaring via stages of aan goede simulaties van de praktijk in cursussen. 'Vicarious experiences' of 'plaatsvervangende ervaringen' ontstaan door het percipiëren van andermans succes, waarbij de impact van deze ervaringen groeit naarmate de persoon die men percipieert meer lijkt op de observant. In het hoger onderwijs kunnen deze ervaringen bijvoorbeeld versterkt worden door (succesvolle) alumni te laten spreken voor studenten. Van 'social persuasion' of 'sociale overreding' is sprake als mensen overtuigd worden dat ze beschikken over bekwaamheden die nodig zijn om een bepaalde activiteit de meester te zijn. Dergelijke overreding stimuleert hen om zich meer in te spannen en gemotiveerd te blijven om hun doelen te bereiken. In het hoger onderwijs spelen docenten en tutoren volgens Dacre Pool \& Sewell hier een belangrijke rol in door (positieve) feedback te geven aan studenten.

\section{Self-confidence}

Waar 'zelfeffectiviteit' betrekking heeft op de zelfingeschatte bekwaamheid om een bepaalde situatie de meester te zijn, heeft 'zelfvertrouwen' betrekking op de wijze waarop deze zelfingeschatte bekwaamheid geprojecteerd wordt naar de buitenwereld. 'Zelfvertrouwen' is daarmee iets dat 'gepresenteerd' en 'gezien' kan worden. In hoeverre dit zelfvertrouwen aangeboren of ontwikkeld kan worden, en in hoeverre het contextspecifiek is niet eenduidig te beantwoorden. Als het als een karaktereigenschap wordt beschouwd en derhalve vrij stabiel is over de tijd, is het volgens Norman \& Hyland (2003) onwaarschijnlijk dat het verder ontwikkeld kan worden binnen het onderwijs. Als 'zelfvertrouwen' echter als contextspecifiek concept wordt beschouwd dat samenhangt met de zelfeffectiviteit, zoals Dacre Pool \& Sewell in hun model doen, dan is het mogelijk om dit vertrouwen in bepaalde situaties te verbeteren door de zelfeffectiviteit te vergroten. 


\section{Self-esteem}

Naast de inschatting van wat iemand 'kan' (zelfeffectiviteit) en de wijze waarop men dit 'uitstraalt' (zelfvertrouwen), speelt ook realiteitszin een rol in 'employability'. Dit element is ondergebracht in het concept 'self-esteem' of (in dit geval) 'zelfbewustzijn'. Het psychologische construct 'self-esteem' heeft volgens Owens (1993) twee dimensies: namelijk positieve evaluaties én negatieve evaluaties. Bij mensen kan het ene type evaluaties boven het andere type overheersen, maar het één zonder het ander komt zelden voor en is ook niet wenselijk. Een positieve eigenwaarde is immers goed, maar een mate van realiteitszin is dat ook. Deze realiteitszin is een gevolg van reflectie, en reflectie is bijvoorbeeld essentieel om successen (positieve ervaringen en evaluaties) in perspectief te kunnen zetten (negatieve evaluaties), en zorgt ook voor bewustzijn over wat men bijvoorbeeld nog niet kan (negatieve evaluaties) maar nog wel zou kunnen bijleren (positieve evaluaties). Een goede balans tussen positieve en negatieve evaluaties en daarmee een sterk zelfbewustzijn draagt bij aan iemands 'employability', of zoals Steinem (1992, p.26) stelt: "self-esteem isn't everything; it's just that there's nothing without it." 



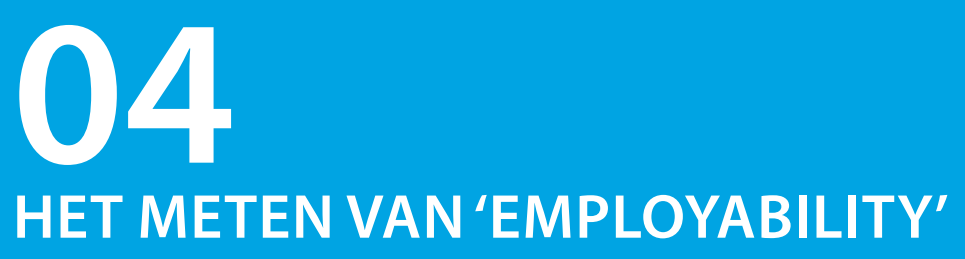

\section{1 'Objectieve' en 'subjectieve' maatstaven}

Net zoals er geen standaardtheorie over 'employability' van afgestudeerden bestaat, bestaat net zo min één standaard-meetinstrument om het concept te meten. Ruwweg kunnen we in de 'employability' literatuur twee hoofdstromingen onderscheiden als het gaat om het meten van (dimensies van) het concept: namelijk de 'objectieve' en 'subjectieve' maten (o.a. Okay-Sommerville \& Scholarios, 2015). Bij het eerste, veelvoorkomende type gaat het vooral om het in kaart brengen van verschillen in 'harde' uitkomsten op de arbeidsmarkt. Bij het tweede type maten ligt de nadruk vooral op het beoordelen van (gepercipieerde) persoonlijke eigenschappen; deze eigenschappen worden vaak geschaard onder de noemer 'employability skills' (o.a. Saterfiel \& McLarty, 1995; Bakar \& Hanafi, 2007).

Hoewel 'employability' ook gemeten zou kunnen worden door bijvoorbeeld de arbeidsmarktcontext in kaart te brengen (denk aan Brown et al., 2003), of door deelname aan 'employability'-verruimende activiteiten te meten (Forrier \& Sels, 2005), lijken deze typen indicatoren in de praktijk veel minder voor te komen. We laten deze varianten hier daarom buiten beschouwing.

\subsubsection{Objectieve maten: feitelijke arbeidsmarktuitkomsten}

Bij de 'objectieve' maten van 'employability' draait het om de feitelijke arbeidsmarktuitkomsten (ook wel 'professioneel succes') en de verschillen die daar tussen groepen bestaan. Deze indicatoren zijn ruwweg te clusteren onder het vinden van werk, en indien men werk heeft: de arbeidsvoorwaarden en de functie-inhoudelijke aspecten. Het vinden van werk is het meest elementaire en meest gebruikte aspect om 'employability' in kaart te brengen. Het gaat dan vooral om het wel of niet hebben van een baan (o.a. Smith, McKnight \& Naylor, 2000; Lim, 2010; Firpo, Carvalho \& Pieri, 2016) en de duur van de zoekperiode om werk te vinden (o.a. Lim, 2010; Allen \& Coenen, 2011). Als het gaat om de arbeidsvoorwaarden, kan onder meer gekeken worden naar of men een fulltime of parttime aanstelling heeft, of men een vast, tijdelijk of ander type dienstverband heeft en wat de hoogte van de lonen is (o.a. Allen et al., 2009; Firpo, Carvalho \& Pieri, 2016). Een functie-inhoudelijke indicator van 'employability' betreft bijvoorbeeld het wel of niet hebben van een leidinggevende functie en het hebben van een baan op het 
eigen opleidingsniveau en/of in de eigen richting (o.a. Allen et al., 2009; Allen \& Coenen, 2011)

\subsubsection{Subjectieve maten: competenties en eigenschappen}

Bij 'subjectieve' maten gaat het om inschattingen van persoonlijke competenties en/ of persoonseigenschappen. Een uitgebreide studie naar dit type indicatoren is verricht door Smith, Ferns \& Russell (2014). Volgens hen bestaat 'employability' uit een twaalftal hoofddimensies, namelijk "lifelong learning; professional practices and standards; integration of knowledge/theory and practice; informed decision-making (applied information literacy); commencement readiness; and collaboration" (p.1). Volgens de auteurs kunnen deze dimensies gemeten worden aan de hand van 35 vragenlijstitems waarop men zichzelf een score moet toekennen. Het gaat voor de dimensie 'collaboration' dan bijvoorbeeld om de mate waarin men zichzelf capabel acht om 'iedereen het gevoel te geven gehoord te worden in groepsdiscussies', 'effectief en respectvol te interacteren met mensen uit andere culturen' en 'bij tegengestelde opvattingen tot een compromis te komen die het beste is voor de organisatie'.

Een ander voorbeeld van een 'subjectieve maatstaf' betreft het 'dispositional measure of employability' van Fugate \& Kinicki (2008). Dit instrument legt de nadruk op het psychosociale aspect van 'employability', oftewel 'dispositional employability'. Fugate (2006) omschrijft dit als: "a constellation of individual differences that predispose employees to (pro)actively adapt to their work and career environments. Employability facilitates the identification and realization of job and career opportunities both within and between organizations. Conceived this way, employability is a disposition that captures individual characteristics that foster adaptive behaviors and positive employment outcomes" (p. 20). Om dit concept te meten ontwikkelden Fugate \& Kinicki (2008) een vijfdimensioneel vragenlijstinstrument, bestaande uit 25 items. De vijf dimensies betreffen 'work and career resilience, openness to changes at work, work and career proactivity, career motivation en work identity'. In de vragenlijst wordt gevraagd in hoeverre de 25 uitspraken de respondent beschrijven ${ }^{3}$. Zo bestaat de dimensie 'open staan voor veranderingen op het werk' bijvoorbeeld uit de uitspraken 'Ik vind dat veranderingen op het werk over het algemeen positieve implicaties hebben', 'Ik vind dat ik veranderingen op het werk over het algemeen accepteer' en 'Ik ben in staat om mij aan te passen aan veranderende werkomstandigheden'.

\subsubsection{Tussenvormen van 'subjectief' en 'objectief'}

Voornoemde 'subjectieve' indicatoren hebben betrekking op hoe personen 'zijn' en hebben daarmee niet noodzakelijkerwijs een relatie met het hebben van een baan of de eigenschappen van die baan op zich. Toch zijn er ook een aantal subjectieve indicatoren (want gebaseerd op een persoonlijke mening) voor 'employability' die wèl een directe relatie leggen met de baan en dus met de arbeidsmarktsituatie. We zouden deze daarom kunnen beschouwen als een soort tussenvorm van 'objectief' (arbeidsmarktgerelateerd) en 'subjectief' (eigen perceptie). Het gaat dan bijvoorbeeld om inschattingen 
van de mate waarin de huidige baan aansluit op de competenties van personen (o.a. Allen \& Coenen, 2011). Naarmate deze competentiematch beter is, kan dit geïnterpreteerd worden als een betere 'employability'. Ook de baantevredenheid (o.a. Allen \& Coenen, 2011) kan als subjectieve, maar baangerelateerde indicator worden beschouwd. Deze indicator sluit bijvoorbeeld nadrukkelijk aan bij de 'employability'-definitie van Yorke (2006) die stelt dat het niet alleen gaat om het verkrijgen van een baan, maar onder andere ook om het hebben van een baan waarin men zich prettig voelt.

\subsection{Meetinstrumenten en de relatie met definities}

De wijze waarop 'employability' gemeten wordt, dient gebaseerd te zijn op de achterliggende, theoretische definitie van het concept, zo redeneert Harvey (2001) in 'Defining and Measuring Employability'. Volgens de auteur worden de indicatoren van 'employability' vaak verward met het concept 'employability' op zich. Zo worden werkloosheidscijfers vaak gelijkgesteld aan 'de mate van employability', terwijl dit slechts een indicatie van het bredere concept geeft. Harvey stelt dat de gehanteerde maatstaf ingegeven te zijn door het theoretische uitgangspunt van het concept 'employability'. Oftewel: hoe 'employability' gemeten wordt, moet afhangen van hoe men tegenover het concept 'employability' aankijkt.

Harvey geeft drie voorbeelden van gangbare definities van 'employability' en destilleert vanuit deze theoretische uitgangspunten diverse meetinstrumenten. In de eerste definitie wordt 'employability' gezien als het vermogen om werk te vinden en te behouden (ruwweg de basisdefinitie van Hillage \& Pollard, 1998). Dit theoretische concept kan ontleed worden in verschillende dimensies zoals het type werk en dienstverband, de benodigde tijd om werk te vinden en de hoogte van het inkomen. Vanuit deze dimensies en indicatoren dient focus aangebracht te worden en een selectie gemaakt te worden, bijvoorbeeld focus op 'heeft de afgestudeerde binnen zes maanden werk gevonden?'. Het meetinstrument dat hier vervolgens het beste bij past is een survey onder afgestudeerden naar hun arbeidsmarktpositie. Met dit meetinstrument kan de beslissing gemaakt worden om een eenvoudige indicator als 'het hebben van werk' te gebruiken om 'employability' te indiceren.

In de tweede voorbeelddefinitie wordt 'employability' beschouwd als de mate waarin afgestudeerden eigenschappen (kunnen) tonen die werkgevers nodig achten voor het functioneren van hun organisatie (o.b.v. Harvey, 1999). Deze definitie kent diverse onderliggende dimensies, zoals eigenschappen op het gebied van samenwerken, leiderschap en communicatie. Indicatoren van deze dimensies zijn dan bijvoorbeeld communicatieve vaardigheden of ervaring met het werken in teamverband. Dit vereist een meetinstrument dat een afgebakend scala van deze capaciteiten van afgestudeerden kan meten. Scores van afgestudeerden op deze capaciteiten geven uiteindelijk 'de' mate van 'employability' weer. 
Een derde voorbeelddefinitie omschrijft 'employability' als het vermogen van afgestudeerden om een bevredigende baan te kunnen vinden. Een invulling die onder meer raakvlakken heeft met de definitie van Yorke (2006). Een bevredigende baan bestaat onder meer bestaan uit de dimensies financieel belonend, verantwoordelijk en interessant werk. Het meetinstrument kan dan een tevredenheidsenquête onder werkende afgestudeerden zijn, waarin een scala van tevredenheidsindicatoren worden meegenomen.

\subsection{Kritiekpunten bestaande meetinstrumenten}

In de praktijk wordt 'employability' vooral gemeten aan de hand van 'harde' outputindicatoren op de arbeidsmarkt in relatie tot het hoger onderwijs, vooral in termen van werkloosheidspercentages per instelling of per opleiding. (Harvey, 2001). Volgens Harvey heeft dit niet zozeer te maken met een kokervisie die het 'verkrijgen van werk' bijvoorbeeld prioriteert boven 'arbeidsmarktvoorbereidende eigenschappen', maar simpelweg omdat arbeidsmarktuitkomsten eenvoudig te meten zijn. Door 'employability' te meten aan de hand van arbeidsmarktuitkomsten in relatie tot instellingen (of opleidingen), gaat het vooral om het meten van de veronderstelde 'effectiviteit van de instelling'.

Harvey stelt dat de rol van de instellingen daarmee sterk wordt overschat: "institutions can do no more than play their part, through the experience they provide for their students, in encouraging and enabling students to become employable." (p.99). Natuurlijk leveren instellingen en opleidingen een bijdrage aan 'employability' door het verschaffen van kennis en het aanleren van vaardigheden, maar het negeert de ontwikkeling die men buiten het hoger onderwijs doormaakt. Zo kan er sprake zijn van selectie-effecten, bijvoorbeeld omdat scholieren met bepaalde eigenschappen kiezen voor bepaalde instellingen en opleidingen. Outputindicatoren kunnen daarmee een weergave zijn van verschillen in eigenschappen tussen afgestudeerden die zij al vóór hun studie bezaten. Daarnaast ontwikkelt men zich ook tijdens de studieperiode buiten het onderwijs, bijvoorbeeld omdat men een baan heeft of omdat men extra-curriculaire activiteiten onderneemt. Wanneer 'employability' gemeten wordt aan de hand van arbeidsmarktuitkomsten is het daarom moeilijk, zo niet onmogelijk, te onderscheiden welk deel toe te schrijven is aan het hoger onderwijs en welk deel aan andere factoren.

Een ander probleem bij het gebruiken van arbeidsmarktuitkomsten als indicatoren voor 'employability' in termen van de 'effectiviteit van instellingen', heeft te maken met de irrationaliteit van de arbeidsmarkt. In een theoretische, volledig rationele arbeidsmarkt zullen werkgevers op zoek gaan naar werkzoekenden die beschikken over optimale kennis en vaardigheden. Instellingen en opleidingen die hun studenten kennis en vaardigheden het 'best' weten aan te leren, zullen daarmee het 'effectiefst' zijn en de meest'employable' afgestudeerden afleveren. In de werkelijkheid selecteren werkgevers volgens Harvey ook op andere gronden, waarbij persoonlijke voorkeuren, 'voorgevoel' en 'vooroordelen' een rol kunnen spelen. Arbeidsuitkomsten zijn dan ook lang niet altijd 
enkel een rechtstreeks 'gevolg' van de effectiviteit van instellingen dan wel de 'harde' kwaliteiten van afgestudeerden.

Zo kan de compositie van de studentenpopulatie (richtingen, leeftijd, geslacht enzovoorts) sterk tussen instellingen verschillen, waardoor het gebruik van arbeidsmarktuitkomsten om de 'effectiviteit van instellingen' te meten, gecompliceerd wordt. Harvey onderscheidt een negental aspecten waar rekening mee gehouden moet worden bij het interpreteren van arbeidsmarktuitkomsten als indicatoren van 'employability' c.q. de 'effectiviteit van instellingen':

1. Type hoger onderwijsinstelling: de 'reputatie' van hoger onderwijsinstellingen beïnvloeden de kansen van afgestudeerden op de arbeidsmarkt. Afgestudeerden van 'prestigieuze instellingen' zullen relatief kansrijker zijn dan anderen, ongeacht hun eigenschappen.

2. Studievariant: de uitgangspositie van voltijdstudenten is erg verschillend van die van deeltijdstudenten of duale studenten. Door deeltijd/duale studenten mee te nemen in de arbeidsmarktstatistieken, wordt het beeld vertroebeld, zij hebben doorgaans al een baan tijdens de studie. Door de ze echter níét op te nemen wordt het beeld ook verstoord: het negeert daarmee namelijk de mogelijke verbetering van hun 'employability' door het volgen van een (aanvullende) opleiding.

3. Locatie en mobiliteit: niet alle afgestudeerden zijn geografisch mobiel of willen dat zijn, de arbeidsmarktkansen zijn daardoor regionaal verschillend. Ook werkgevers kunnen voorkeuren hebben voor afgestudeerden uit bepaalde regio's.

4. Studierichtingen: de kansen per opleidingsrichting zijn erg verschillend, en varieren bovendien regionaal en over de tijd. Instellingen met een specifieke richting (bijvoorbeeld technische universiteiten) kunnen ten opzichte van andere instellingen daardoor soms relatief 'effectief' en soms juist 'ineffectief' ogen.

5. Eerdere werkervaring: eerdere werkervaring is een belangrijke factor voor werkgevers en kan zowel betrekking hebben op een eerdere fulltime baan, als op bijbanen tijdens de studie.

6. Leeftijd: werkgevers hebben vaak een voorkeur voor jongeren

7. Etniciteit: discriminatie tegen etnische minderheden kan nog altijd een niet te negeren rol spelen bij werving

8. Geslacht: hoewel in veel organisaties er meer vrouwen worden aangenomen dan mannen, kunnen vrouwen tegen het 'glazen plafond' aanlopen bij hogere functies

9. Sociale klasse: herkomst heeft onder meer invloed op de mogelijkheden om extracurriculaire activiteiten te volgen en mensen uit lagere sociale klassen hebben vaak zwakkere netwerken dan anderen.

\subsection{Alternatief}

Ook wanneer de focus niet wordt gericht op arbeidsmarktuitkomsten, maar bijvoorbeeld op het ontwikkelen van vaardigheden of kennis van studenten tijdens de opleiding, is het volgens Harvey (2001) vrijwel onmogelijk om de bijdrage van het onderwijs 
aan de 'employability' te meten. Volgens de auteur blijft het immers onduidelijk wat studenten binnen en wat ze buiten de instelling ontwikkelen.

Een alternatieve methode om de bijdrage aan de 'employability' te meten waarbij voornoemde belemmeringen minder spelen, is het uitvoeren van een zogenaamde 'employability audit' (Harvey 2000; Harvey, 2001). Een dergelijke audit identificeert onder meer de mogelijkheden die de instelling of de opleiding biedt om werkervaring op te doen en de ontwikkelingsmogelijkheden van individuele eigenschappen (zoals kennis en vaardigheden). Het gaat dan om het aan kunnen tonen van expliciet in het curriculum opgenomen ontwikkelmogelijkheden, zoals vaardigheden op het gebied van het zoeken en verkrijgen van banen. Hoewel deze audit nadrukkelijk geen harde 'effectstudie' is, heeft deze methode als voordeel dat het ontwikkelprocessen in kaart kan brengen en een indicatie geeft van waar en hoe dat proces verbeterd kan worden.

In een dergelijke methode gaat het om zelfrapportage van instellingen en opleidingen, waarbij gebruik gemaakt wordt van een standaard 'raamwerk' om het beheersbaar en vergelijkbaar te houden. De waarheidsgetrouwheid en nauwkeurigheid van de rapportage zou geverifieerd kunnen worden door een externe auditor, of zelfs in geformaliseerde vorm als onderdeel van de reguliere visitatie- en accreditatieprocedures. In de praktijk wordt de 'employability audit' al op diverse plekken ingezet als zelfbeoordelingsinstrument, zoals op de University of Glasgow en de University of Leeds (Hughes \& Macfarlane-Dick, z.j.). 


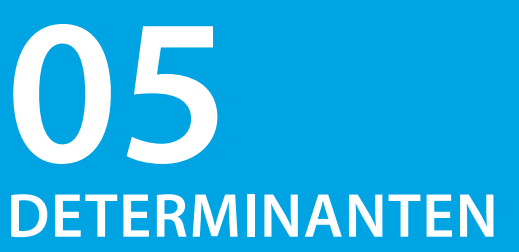

\subsection{Typologie van relevante factoren}

Uit voorgaande hoofdstukken weten we dat de 'employability' literatuur soms een meer individualistisch perspectief hanteert en soms een meer contextueel perspectief. In het individualistische perspectief gaat het vooral om verschillen in de 'set van eigenschappen' die mensen hebben (o.a. Smith, Ferns \& Russell, 2014), waarbij vaak een relatie wordt gelegd met 'employability skills' (arbeidsmarktrelevante vaardigheden die niet vakspecifiek zijn). In de meer contextuele visie worden ook de omstandigheden (zoals de arbeidsmarktsituatie) als relevante factoren beschouwd, een visie die vooral betrekking heeft op de arbeidsmarktkansen van personen (o.a. Brown, Hesketh \& Williams, 2003).

Voor beide invalshoeken valt wat te zeggen en het één sluit het ander niet uit. Individuele eigenschappen zijn natuurlijk relevant, maar contextuele factoren kunnen dat evenzeer zijn. Zeker wanneer we 'employability' beschouwen in termen van arbeidsmarktperspectieven (bijvoorbeeld: de kans op een baan), dan kunnen er op verschillende niveaus factoren een rol spelen. Op basis van de kennis uit de voorgaande hoofdstukken onderscheiden we voor het gemak drie typen factoren: individuele factoren, opleidings- en instellingsspecifieke factoren en arbeidsmarktfactoren.

\subsection{Individuele factoren}

leder mens is uniek, ieder persoon verschilt in zijn/haar combinatie van eigenschappen. Deze unieke'set'van eigenschappen staat in het brede scala aan'employability' modellen centraal. Op welke typen individuele eigenschappen de nadruk gelegd wordt, verschilt van model tot model. Eén van de meest uitgebreide modellen (gebaseerd op diverse eerdere modellen) betreft het 'The key to employability model' van Dacre Pool \& Sewell (2007). In dit model worden een vijftal 'typen 'individuele factoren onderscheiden die een rol spelen bij de 'employability' van afgestudeerden.

Het gaat dan om Career development learning (kennis en zelfbewustzijn op het gebied van loopbaanontwikkeling); Experience (zowel praktijkervaring bijvoorbeeld uit werk of stages, maar ook levenservaring in bredere zin); Degree subject knowledge, under- 
standing \& skills (vakspecifieke kennis en vaardigheden, vaak de meest 'harde' maatstaf waarlangs afgestudeerden kunnen worden gelegd); Generic skills (vaak ook 'employability' skills genoemd, oftewel generieke vaardigheden die men breed in kan zetten zoals creativiteit, flexibiliteit en leergierigheid); en Emotional intelligence (kort gezegd het vermogen om om te kunnen gaan met de eigen emoties en met die van anderen). Waar het hoger onderwijs zich van oudsher vooral richtte op de ontwikkeling van academische en vakspecifieke vaardigheden, wordt er steeds meer aandacht besteed aan nietvakspecifieke, brede arbeidsvaardigheden. De opkomst van de kenniseconomie wordt daarvoor veelvuldig als drijvende kracht voor genoemd: in een hoogtechnologische en snel veranderende wereld worden algemene vaardigheden steeds belangrijker geacht (o.a. Fallows \& Steven, 2000).

Naast voornoemde factoren die vooral iets zeggen over de kwaliteiten van individuen spelen volgens Harvey (2001) echter nog een aantal andere aspecten die van invloed zijn op iemands baankansen. Het kan dan bijvoorbeeld gaan om de mogelijkheid en bereidheid om te reizen of te verhuizen voor werk, of om het hebben en kunnen inzetten van een persoonlijk netwerk om werk te vinden. Ook 'vaststaande' persoonskenmerken die niet noodzakelijkerwijs met kwaliteit te maken hebben, kunnen een rol spelen. Zo kan er sprake zijn van discriminatie op de arbeidsmarkt jegens vrouwen, ouderen of allochtonen. Ook de sociale klasse waar iemand uit afkomstig is kan volgens Blasko et al. (2002) een rol spelen. Deels via indirecte onderwijseffecten, bijvoorbeeld omdat zij minder toegang hebben tot betere (duurdere) instellingen, maar ook via directe effecten. De auteurs signaleren dat personen uit lagere sociale klassen het moeilijker hebben op de arbeidsmarkt, zelfs wanneer zij dezelfde onderwijsachtergrond hebben als anderen.

\subsection{Opleidings- en instellingsspecifieke factoren}

De rol van de opleiding of de instelling loopt voor een belangrijk deel via de individuele factoren. Zo heeft de keuze voor een specifieke opleiding (of bijvoorbeeld voor een instelling met een specifiek karakter zoals een technische universiteit) logischerwijs gevolgen voor de ontwikkeling van iemands vakkennis en vakspecifieke vaardigheden. Ook op andere manieren spelen opleidingen en instellingen een rol, bijvoorbeeld bij het ontplooien van niet-vakspecifieke vaardigheden ('generic skills' zoals communicatievaardigheden) of door arbeidsmarktbewustzijn te vergroten via loopbaanoriëntatie.

Naast de inspanningen van opleidingen en instellingen voornoemde aspecten bij studenten te ontwikkelen (vakkennis, generieke vaardigheden enzovoorts), kunnen zij ook op hele andere manieren van invloed zijn op de arbeidsmarktkansen van afgestudeerden. Zo geeft Harvey (2001) aan dat alleen al de reputatie van de instelling de baankansen van afgestudeerden beïnvloedt, ongeacht de eigenschappen van de afgestudeerde. Een hoge score op 'kwaliteitsrankings' (zoals de World University Rankings) of 'employability rankings' (zoals de Graduate Employability Rankings), lijkt afgestudeerden dus te kunnen helpen bij hun arbeidsmarktkansen. Hesketh (2000) toont aan dat werkgevers inderdaad voorkeuren hebben voor bepaalde instellingen, bijvoorbeeld 
voor instellingen met hoge instroomvereisten of 'traditionele' universiteiten met een lange geschiedenis. Ter nuance: uit de Britse studie van McGuinness (2003) volgt dat de arbeidsmarktuitkomsten van afgestudeerden wel nog altijd sterker beïnvloed worden door de studierichting die zij hebben gevolgd dan door de specifieke instelling waaraan zij studeerden.

\subsection{Arbeidsmarktfactoren}

De arbeidsmarktomstandigheden spelen een grote rol bij de kans op werk. Het feit dat het werkloosheidspercentage onder afgestudeerden van jaar tot jaar verschilt (VSNU, 2016) duidt immers eerder op conjuncturele ontwikkelingen, dan op jaarlijkse verschillen in de 'employability' van werkzoekenden. Brown et al. (2003) stellen zelfs dat de kans op werk voor afgestudeerden vooral bepaald wordt door arbeidsmarktontwikkelingen, eerder dan door hun capaciteiten. 'Employability' varieert daardoor naar gelang de economische situatie: in hoogconjunctuur zijn afgestudeerden, onafhankelijk van hun eigenschappen, meer 'employable' en in tijden van economische achteruitgang 'minder'employable'.

De rol van de arbeidsmarkt is onmiskenbaar en de relevantie wordt zelfs onderschreven door wetenschappers die 'employability' juist relateren aan de eigenschappen van het individu. Zo stelt Yorke (2006) bijvoorbeeld dat het beschikken over 'wenselijke' eigenschappen geen garantie is op werk. Diverse externe variabelen spelen namelijk een belangrijke rol, zoals de nationale, regionale en/of lokale economische 'gezondheid' en de vraag-aanbod ratio van specifieke'wenselijke' eigenschappen. 



\section{6 \\ HET BEVORDEREN VAN ‘EMPLOYABILITY SKILLS': EMPIRIE}

\section{1 'Employability' en empirie}

Ondanks de complexiteit van 'employability' in termen van definities, uiteenzettingen en meetbare indicatoren, staat het vergroten van de 'employability' van studenten wereldwijd op de agenda van het hoger onderwijs (Cranmer, 2006). Het is echter de vraag in hoeverre het hoger onderwijs daadwerkelijk een significante bijdrage kan leveren aan de inzetbaarheid van afgestudeerden als het gaat om de ontwikkeling van niet-vakspecifieke competenties en of dergelijke competenties er überhaupt 'toe doen'.

We hanteren in dit hoofdstuk daarmee een 'smalle' definitie van 'employability' waarin vakspecifieke kennis en vaardigheden buiten beschouwing worden gelaten. Het is immers vanzelfsprekend dat het volgen van een opleiding deze vakspecifieke competenties verbetert. Hoewel het aantal empirische studies naar de invloed van niet-vakspecifieke 'employability'-competenties zeer schaars is (aldus o.a. Cranmer, 2006; Jackson, 2013), behandelen we in dit hoofdstuk een aantal onderzoeken die hier meer licht op kunnen schijnen.

\subsection{Nadruk op 'employability skills' (Cranmer, 2006)}

In de Britse studie van Cranmer uit 2006 is de bijdrage van het hoger onderwijs aan de 'employability' van studenten onderzocht via case studies op acht universiteiten (o.a. gesprekken met academisch personeel), via gegevens uit een landelijke afgestudeerdenenquête, via telefonische interviews met afgestudeerden aan de acht universiteiten en via telefonische interviews met de directe leidinggevenden van de afgestudeerden. In het onderzoek wordt de mate van aandacht voor 'employability' gemeten door aan het academisch personeel te vragen in hoeverre er in het onderwijs nadruk ligt op 'employability skills' zoals communicatie, ICT-vaardigheden en probleemoplossend vermogen ten opzichte van de meer 'conventionele' academische vaardigheden zoals vakspecifieke kennis en theoretisch begrip".

4 Vierpuntsschaal: 4 = Very high emphasis placed on employability skills in teaching; $3=$ =Fairly high emphasis, 2 = Fairly low emphasis, 1 = Very low emphasis 
Uit het onderzoek volgt dat hoewel universitair afgestudeerden het ten opzichte van andere afgestudeerden relatief goed doen op de arbeidsmarkt (lagere werkloosheid, hogere lonen) er geen duidelijke bevestiging wordt gevonden dat nadruk op 'employability skills' tijdens de opleiding invloed heeft op arbeidsmarktuitkomsten. Volgens de auteur heeft dit vermoedelijk te maken met een 'mismatch' tussen de verworven vaardigheden op de universiteit en de benodigde vaardigheden op de arbeidsmarkt. Dit vermoeden wordt bevestigd door de interviews met de leidinggevenden van afgestudeerden. Zij geven aan dat de afgestudeerden slechts over enkele of zelfs géén van de vaardigheden beschikken die benodigd waren toen zij de baan begonnen. De grootste tekorten liggen volgens de leidinggevenden op het gebied van kennis en vaardigheden, waarbij het zowel gaat om technische en/of werkgever-specifieke competenties, als om de meer generieke 'employability' vaardigheden.

Afgestudeerden lijken dus weinig 'baat' te hebben bij de tijdens de opleiding aangeleerde, meer generieke 'employability' vaardigheden. Wel vindt de auteur een duidelijke positieve invloed van 'structured work experience' (externe stages) tijdens de opleiding. Deze afgestudeerden blijken beter in staat om binnen zes maanden na afstuderen werk te vinden op hun eigen niveau. Ook vindt Cranmer dat naarmate er een grotere betrokkenheid van werkgevers is bij het ontwerpen en verzorgen van cursussen, afgestudeerden een succesvollere transitie naar de arbeidsmarkt maken.

Hoewel sommige afgestudeerden dus een soepelere transitie maken, bijvoorbeeld vanwege hun eerdere praktijkervaring, is het voorstelbaar dat de initiële verschillen in competenties tussen afgestudeerden snel kleiner worden als zij enkele jaren werkervaring hebben en daar meer beroepsspecifieke kennis en vaardigheden aangeleerd krijgen. Zo vindt Little (2003) in haar landenvergelijkende studie dat afgestudeerden na enkele jaren arbeidsmarktervaring nauwelijks nog competentietekorten ervaren in hun werk: "This could be interpreted as suggesting the "problem" may be more one of transitions into the labour market rather than of longer-term enduring mismatches between labour market supply and demand." (p.22). Gezien deze bevinding ligt er dus vooral een uitdaging voor het hoger onderwijs om de initiële transitie van opleiding naar werk te verbeteren, bijvoorbeeld door meer in te zetten op beroepspraktijkvorming en het beroepenveld nadrukkelijk te betrekken bij het onderwijs.

\subsection{Mason, Williams \& Cranmer (2009)}

In Mason, Williams \& Cranmer (2009) wordt de hiervoor benoemde studie uitgebreid met aanvullende componenten die de arbeidsmarktkansen van afgestudeerden kunnen beïnvloeden. Wederom kijken de auteurs naar de mate waarin 'het aanleren (en evalueren) van 'employability skills' bijdraagt aan de kans op werk, maar ook wordt gekeken naar de mate waarin werkgevers betrokken worden bij het onderwijs, en of studenten tijdens de opleiding praktijkervaring hebben opgedaan via een 'sandwich courses's.

"A college course consisting of periods of study with periods of work between them so that students get practical experience" (uit: Cambridge Dictionary). 
De mate waarin aandacht wordt besteed aan het aanleren en evalueren aan 'employability skills' wordt gemeten aan de hand van zelfevaluaties door faculteiten. Representanten van de faculteiten kenden scores (van 1 tot 4 ) toe aan drie aspecten, namelijk de nadruk op 'employability skills' 6 in het onderwijs, de nadruk op 'employability skills' in de beoordeling van studenten en het relatieve belang dat aan 'employability skills' wordt gehecht ten opzichte van vakkennis. De mate waarin werkgevers worden betrokken bij het onderwijs 7 is 'gescoord' (van 1 tot 4 ) door de onderzoekers zelf op basis van faculteitsdocumentatie en gesprekken met sleutelfiguren. Vervolgens zijn de student- en faculteitskenmerken gekoppeld aan arbeidsmarktuitkomsten van de studenten, een half jaar na afstuderen.

Uit de analyses van Mason et al. volgt dat het opdoen van 'gestructureerde werkervaring' tijdens de opleiding een sterk positief effect heeft op de kans op werk én op de kans om een baan op niveau te vinden. Ook blijkt dat binnen faculteiten waar werkgevers nadrukkelijker betrokken zijn bij het onderwijs, studenten een grotere kans hebben op het vinden van een baan op niveau. Er wordt echter, in lijn met de studie van Cranmer (2006), wederom géén bewijs gevonden dat een sterkere nadruk op 'employability skills' in het onderwijs de arbeidsmarktkansen van studenten beïnvloedt.

De auteurs redeneren op basis van de resultaten dat het onderhouden van banden met het bedrijfsleven voor instellingen nuttig en belangrijk is. Enerzijds om werkgevers te betrekken bij de ontwikkeling en uitvoering van cursussen, en anderzijds om werkgevers in het netwerk te hebben als mogelijke plekken waar studenten werk- en praktijkervaring op kunnen doen. Het feit dat nadruk op 'employability skills' in het onderwijs geen significante invloed lijkt te hebben op de arbeidsmarktkansen, geven volgens de auteurs aan dat de ontplooiing van studenten als 'arbeidskrachten' vooral plaats vindt binnen de muren van werkgevers, en moeilijk aan te leren en te incorporeren is in het onderwijs.

\subsection{Career management skills (Bridgstock, 2009)}

In de literatuurstudie van Bridgstock (2009) wordt de invloed van 'career management skills' op arbeidsmarktuitkomsten geanalyseerd. Bij deze vaardigheden op het gebied van loopbaanbeheer gaat het volgens de auteur om: "the abilities required to proactively navigate the working world and successfully manage the career building process, based on attributes such as lifelong learning and adaptability" (pp.34-35). Meer concreet gaat het bijvoorbeeld om het bekend zijn met de arbeidsmarkt (zoals het beschikken over arbeidsmarktinformatie, kennis van de beroepenstructuur en dergelijke), het hebben van inzicht in een gezonde loopbaanontwikkeling (zoals het volgen van scho-

\footnotetext{
6 Op het gebied van communicatie, gecijferdheid, geletterdheid, ICT, probleemoplossend vermogen, begrip van de arbeidsmarkt en samenwerken.

7 Op het gebied van planning en ontwikkeling van de cursussen, het verzorgen van het onderwijs én beoordeling van de studenten.
} 
ling wanneer nodig, het veranderen van taken of functies), het weten waar men banen kan zoeken en hoe men dient te solliciteren, en het belang inzien en het benutten van sociale netwerken.

Uit de literatuurstudie volgt dat er goede aanwijzingen zijn dat grotere 'career management skills' de 'employability' inderdaad verbetert. Zo volgt uit Werbel (2000) dat studenten die meer tijd hebben besteed aan arbeidsmarktoriëntatie (zoals het deelname aan loopbaanoriëntatieprogramma's of het opzoeken van informatie over beroepen of werkgevers) na afstuderen actiever op zoeken gingen naar werk (bijvoorbeeld vaker solliciteren en het cv bijwerken) en ook banen met hogere lonen vinden. Marmaros \& Sacardote (2001) tonen op hun beurt aan dat afgestudeerden die sociale netwerken kunnen inzetten, met name wanneer zij hun 'fraternity' of 'sorority' netwerk benutten, vaker in hogere, beter betaalde banen terechtkomen.

Hoewel 'career management skills' dus nuttig lijken voor de 'employability' van afgestudeerden, signaleert Bridgstock dat er op universiteiten nauwelijks aandacht wordt besteed aan deze vaardigheden. Wel is er volgens de auteur sprake van een internationale trend onder universiteiten naar groeiend bewustzijn van en gevoel van verantwoordelijkheid voor de 'employability' van hun studenten. Bridgstock stelt dat universiteiten meer in moeten zetten op het ontplooien van de 'career management skills' bijvoorbeeld door grotere aandacht voor loopbaanoriëntatie en via een nadrukkelijkere band met werkgevers op de arbeidsmarkt. Wel is er volgens de auteur meer onderzoek nodig naar de langetermijneffecten van 'career management skills', alsook naar de kostenefficiëntie van het sterker inzetten op deze vaardigheden.

\section{5 'Employability skills' ter compensatie (Wilton, 2011)}

Wilton (2011) onderzoekt in zijn studie in hoeverre 'employability skills' kunnen fungeren als compenserende factor om achterstanden te nivelleren. De auteur maakt hiervoor gebruik van enquêtedata onder Britse afgestudeerden, waarin de arbeidsmarktpositie en -historie van de afgestudeerden werden bevraagd, de attitudes van deze afgestudeerden ten opzichte van hun baan en loopbaan, en hun persoonlijke achtergrond. Om sectorale verschillen uit te sluiten als verklaring voor de arbeidsmarktuitkomsten worden in de studie alleen afgestudeerden uit de richting 'Business \& Management' geselecteerd. Binnen deze richting worden drie typen onderscheiden: specialistische $B \& M$-opleidingen, generalistische B\&M-opleidingen en generalistische opleidingen met nadruk op B\&M.

In de enquête zijn de afgestudeerden gevraagd om in te schatten in hoeverre hun opleiding heeft bijgedragen aan een twaalftal 'employability skills's. Het gaat dan onder meer om vaardigheden op het gebied van schriftelijke communicatie, gesproken communicatie, samenwerken, onderzoeksvaardigheden en digitale geletterdheid. De scores op deze twaalf vaardigheden zijn in de studie gebundeld in één index, waardoor er variatie

$\overline{8}$ 3-puntsschaal: $1=$ not at all, $2=$ some, $3=$ a lot 
ontstaat tussen de respondenten in de mate waarin zij deze 'employability skills' (in hun perceptie) zijn aangeleerd.

In Wiltons analyse wordt gekeken naar vijf 'traditionele' aspecten waarvan bekend is dat deze arbeidsmarktuitkomsten beïnvloeden (geslacht, type hogeronderwijsinstelling, leeftijdsgroep, etniciteit en type opleiding) en naar de mate van 'employability skills'. Wilton concludeert dat er geen duidelijke compensatie uitgaat van deze vaardigheden. Zo hebben vrouwen en etnische minderheden een hogere score op de 'employability index', maar hebben zij nog altijd slechtere arbeidsmarktuitkomsten, zoals lagere lonen en een kleinere kans op werk op eigen niveau of in leidinggevende banen. Dit ondanks het feit dat het hier gaat om een groep afgestudeerden in dezelfde opleidingsrichting, op gelijk opleidingsniveau met hogere 'employability skills'.

Wilton stelt daarom dat er ondanks de groeiende nadruk op 'employability skills' in het onderwijs en ondanks het feit dat sommige afgestudeerden aangeven over meer arbeidsmarktrelevante vaardigheden te beschikken dan anderen, er nog steeds sprake is van traditionele 'belemmeringen'. Volgens de auteur hechten werkgevers nog steeds veel belang aan 'traditionele' persoonseigenschappen zoals geslacht, etniciteit en leeftijd. 'Employability skills' zijn dus niet zomaar dé sleutel tot succes.

Hoewel deze slotconclusie zeer plausibel is, dienen bij het onderzoek wel diverse kanttekeningen te worden geplaatst. Zo gaat het in dit onderzoek om zelfgerapporteerde, bijgeleerde 'employability skills' en niet om een 'harde', absolute meting van deze vaardigheden. Het is dus denkbaar dat studenten die een laag 'beginniveau' hadden, eerder zullen aangeven veel bij te hebben geleerd dan studenten met een hoog 'beginniveau'. Dit betekent nog niet dat zij ook een hoog 'eindniveau' hebben bereikt. Een andere kanttekening is dat het onduidelijk is blijft 'employability skills' er überhaupt toe doen, en of er wellicht nog grotere groepsverschillen in arbeidsmarktuitkomsten zouden bestaan als er géén aandacht voor deze vaardigheden zou zijn binnen het onderwijs.

\subsection{Aanleren van 'employability skills'}

Op basis van voorgaande studies lijken er weinig aanwijzingen dat het aanleren van de meer 'klassieke' 'employability skills' (zoals communicatie, ICT, gecijferdheid) binnen de kaders van het hoger onderwijs een concrete bijdrage leveren aan de arbeidsmarktkansen van studenten. Wel zijn er andere manieren waarop het onderwijs, naast het aanleren van vakspecifieke competenties, ook breder bij kunnen dragen aan de arbeidsmarktkansen van studenten. Zo zijn er op basis van de besproken studies goede aanwijzingen dat het aanbieden van stagemogelijkheden binnen de opleiding of het aanbieden van loopbaanoriëntatie-activiteiten wel degelijk nuttig kunnen zijn voor het vinden van werk.

Verder is het denkbaar dat het aanleren van 'employability skills' in het onderwijs op langere termijn wel degelijk zinvol kan zijn. Voorgaande studies richten zich immers op 
arbeidsmarktuitkomsten op de relatief korte termijn. Het is niet onlogisch dat 'employability skills' vooral van belang kunnen zijn bij het maken van een carrièreswitch, zeker wanneer het een switch naar een andere sector betreft. De mate waarin vakspecifieke, dan wel generieke skills van belang zijn, kan van sector tot sector verschillen. Het beschikken over meer 'generieke vaardigheden' zou een dergelijk overstap wellicht kunnen vergemakkelijken. Ook kan geredeneerd worden dat álle opleidingen op zijn minst enige aandacht besteden aan 'employability skills'. Het kan dus best zijn dat deze competenties wel degelijk belangrijk zijn om goed op de arbeidsmarkt te kunnen functioneren, maar dat de onderlinge verschillen tussen studenten wellicht niet zo sterk zijn.

Al met al moet geconcludeerd worden dat de empirie zeker niet ondubbelzinnig positief is over het aanleren van 'employability skills' in het hoger onderwijs. Toch wordt hier door instellingen over het algemeen wel (in meer of mindere mate) op ingezet. De (vooral theoretische) literatuur hierover is zeer uitgebreid, om deze reden beperken we ons hier tot drie voorbeeldinterventies (die niet ook gecombineerd kunnen worden) om 'employability skills' te verhogen. De empirische onderbouwing hiervan is echter niet altijd even sterk.

1. Verbinding praktijk en onderwijs: door in het onderwijs gebruik te maken van zogenaamde 'real world data' kan de aandacht verschoven worden van theorie en abstractie naar analyse, interpretatie en implementatie. Deze 'experiential practicals' (Fallows \& Steven, 2000) kunnen niet alleen helpen om in de toekomstige werkpraktijk situaties te herkennen (en daarmee om te gaan) er zijn ook empirische aanwijzingen dat 'experiential practicals' de motivatie van studenten en hun studiesucces vergroot (Ahmet \& Fallows, 1999).

2. Groepsactiviteiten: Werkvormen waarin studenten met elkaar moeten samenwerken kunnen helpen om hun sociale vaardigheden en teamvaardigheden te verbeteren. Dergelijke werkvormen kunnen echter 'freeridersgedrag' in de hand werken, oftewel: sommigen doen al het werk, anderen doen niets. Er zijn dan ook een aantal voorwaarden voor een succesvolle werkvorm: 'interdependentie' (onderlinge afhankelijkheid, bijvoorbeeld als het hele team gestraft wordt als iemand verzaakt), interactie en doorlopende zelfevaluatie en teamevaluatie (Woods et al., 2000).

3. Probleemgestuurd onderwijs (PGO): PGO wordt vooral zinvol geacht voor disciplines waarin diagnostiek en het ondernemen van actie op basis van de diagnostiek belangrijk is, zoals in de geneeskunde. PGO kan niet alleen bijdragen aan een onderzoekende houding, probleemoplossend vermogen en kennisvergroting, maar ook aan communicatie en teamwork door interactie met de medestudenten die allen hun eigen kennis en vaardigheden met zich meebrengen (Baillie, 1998; Fallows \& Steven, 2000). 


\section{7 \\ CONCLUSIES \& DISCUSSIE}

\subsection{Conclusies}

In dit hoofdstuk kijken we terug op de belangrijkste bevindingen uit voorgaande hoofdstukken. Het doel van de voorliggende literatuurstudie was om een breed beeld te kunnen schetsen van het fenomeen 'employability' in relatie tot het hoger onderwijs, oftewel: waarom is de ene afgestudeerde wellicht kansrijker op de arbeidsmarkt dan de ander? Om hier inzicht in te geven, zijn in de voorgaande hoofdstukken respectievelijk besproken: definities van de term 'employability' (Hoofdstuk 2), theoretische modelleringen van 'employability' (Hoofdstuk 3), manieren om 'employability' meetbaar te maken (Hoofdstuk 4), typen en niveaus van determinanten voor 'employability' (Hoofdstuk 5), en tot slot: de effectiviteit van 'employability skills' en de bijdrage van het hoger onderwijs daaraan. We komen in dit conclusiehoofstuk nogmaals terug op deze thema's, teneinde de onderzoeksvragen uit Hoofdstuk 1 te kunnen beantwoorden.

\subsubsection{Definities}

Er bestaan talloze definities van het concept 'employability' die meestal op elkaar lijken, maar vaak nét een iets andere insteek hebben. Wat ze met elkaar gemeen hebben, is dat 'employability' in ieder geval altijd iets te maken heeft met de arbeidsmarkt en werk. Ruwweg zijn de definities van 'employability' te ordenen zijn op een schaal van 'zeer individualistisch' tot 'zeer contextueel' georiënteerd. Bij de meer 'individualistische' invullingen wordt de nadruk gelegd op de 'set' van persoonlijke eigenschappen waarover iemand bezit, of in Yorke's (2006) woorden: "a set of achievements: skills, understandings and personal attributes", waarvan verondersteld mag worden dat deze aantrekkelijk zijn op de arbeidsmarkt. In deze 'individualistische' definitie gaat het niet zozeer om de feitelijke situatie of iemand met een bepaalde set eigenschappen ook daadwerkelijk werk vindt of heeft, maar of men over een set eigenschappen beschikt die normaliter aantrekkelijk worden beschouwd (door werkgevers).

Tegenover deze 'individualistische' benadering, staat de 'contextuele' benadering. In de meest extreme vorm van deze benadering is iemands 'employability' puur afhankelijk van de arbeidsmarktsituatie. 'Employability' wordt hier zeer expliciet gerelateerd aan het vinden of hebben van werk. Wanneer er op de arbeidsmarkt meer vraag is dan aanbod, zal in principe iedere werkzoekende 'employable' zijn. Andersom: wanneer er meer aanbod is dan vraag, dan kan iemand over een uitstekende set eigenschappen beschikken, maar nog niet per definitie werk vinden. 
In de praktijk bestaan de meest gangbare definities van 'employability' uit 'mengvormen' van deze invullingen. In dergelijke definities gaat het vaak om de 'relatieve kansen' van individuen op de (conjunctuurgevoelige) arbeidsmarkt, gegeven hun specifieke set van eigenschappen. Hierin wordt dus zowel verondersteld dat individuele verschillen, alsook de context van invloed is op iemands arbeidsmarktkansen. Afhankelijk van de specifieke definitie kan de focus vooral liggen op het krijgen van werk, het behouden van werk, het tevreden zijn met werk, het mobiel kunnen zijn op de arbeidsmarkt enzovoorts. Kortom: er is géén standaarddefinitie van 'employability'.

\subsubsection{Type factoren}

Als we uitgaan van deze gangbare 'tussenvorm', namelijk dat de 'employability' van studenten/afgestudeerden zowel wordt bepaald door individuele eigenschappen alsook contextuele kenmerken, kunnen we ruwweg drie typen factoren onderscheiden die een rol spelen bij 'employability'. Individuele factoren, opleidings- en instellingsspecifieke factoren en arbeidsmarktfactoren.

Onder individuele factoren is een schier oneindig aantal relevante persoonskenmerken te onderscheiden. leder theoretisch of empirisch model van 'employability' neemt weer andere aspecten mee. Een goed uitgangspunt is het model van Dacre Pool \& Sewell (2007), aangezien dit een vrij'praktisch' model is dat bovendien diverse andere (bekende) modellen integreert. In hun 'The key to employability' model onderscheiden de auteurs een vijftal kernelementen. Ten eerste Career development learning, oftewel kennis en zelfbewustzijn op het gebied van loopbaanontwikkeling. Ten tweede Experience, waarbij het zowel om praktijkervaring (bijvoorbeeld werk of stages) gaat alsook ook levenservaring in algemene zin. Ten derde Degree subject knowledge, understanding \& skills: vakspecifieke kennis en vaardigheden die op de arbeidsmarkt vaak als meest 'meetbare' maatstaf voor studentkwaliteit worden gebruikt. Ten vierde Generic skills, vaak ook'employability' skills genoemd, oftewel generieke vaardigheden die men breed in kan zetten zoals creativiteit, flexibiliteit en leergierigheid. En ten vijfde Emotional intelligence: het vermogen om onder meer om te kunnen gaan met de eigen emoties en met die van anderen. Deze vijf elementen hebben vooral te maken met iemands 'kwaliteiten'. Harvey (2001) stelt echter dat werkgevers niet alleen op kwaliteit selecteren, maar ook op gevoel. Vooroordelen en persoonlijke voorkeuren, bijvoorbeeld voor bepaalde groepen.

Opleidings- en instellingsspecifieke factoren lopen grotendeels via de individuele factoren. Zo heeft de keuze voor een specifieke opleiding gevolgen voor de ontwikkeling van specifieke vakkennis en vakspecifieke vaardigheden. Echter speelt de opleiding (of de instelling) ook een directe rol bij de 'employability' van afgestudeerden. Zo kunnen werkgevers een voorkeur hebben voor studenten vanuit bepaalde instellingen, puur omdat deze een goed 'imago' of sterke 'reputatie' hebben, terwijl dit geen garantie is dat de afgestudeerde zelf ook kwaliteit sterk is.

Arbeidsmarktfactoren spelen vanzelfsprekend een belangrijke rol bij de kansen van afgestudeerden. In veel literatuur wordt 'employability' als een relatief concept gezien, 
oftewel afhankelijk van de specifieke arbeidsmarktsituatie op dat moment en op die plaats. De kans op werk, het type werk, de beloning voor het werk, al deze aspecten zijn mede-afhankelijk van de specifieke arbeidsmarktsituatie (zij het lokaal, regionaal of landelijk) op een bepaald moment.

\subsubsection{Meetbare indicatoren}

Ruwweg zijn er twee typen indicatoren te onderscheiden om 'employability' te meten, objectieve indicatoren en subjectieve indicatoren. De keuze voor het type indicatoren, heeft wederom te maken met de specifieke benadering die men hanteert. Bij de objectieve indicatoren - die veelvuldig gebruikt worden - gaat het om 'harde' arbeidsmarktuitkomsten. Deze indicatoren hebben te maken met het al dan niet vinden van werk, en indien men werk heeft met de arbeidsvoorwaarden en de functie-inhoudelijke aspecten. Objectieve indicatoren zijn daarmee vooral toepasbaar op de meer 'contextuele' benadering: het geeft aan hoe afgestudeerden het op de arbeidsmarkt doen in verhouding tot elkaar, gegeven de specifieke arbeidsmarktsituatie. Bij het tweede type maten ligt de nadruk vooral op het beoordelen van persoonlijke competenties die nuttig geacht worden op de arbeidsmarkt, vaak ook wel 'employability skills' genoemd. Het gaat dan bijvoorbeeld om 'scores' op karakteristieken zoals leergierigheid of flexibiliteit, maar ook om meer concrete competenties zoals teamwork, communicatie en dergelijke. Bij 'subjectieve' indicatoren gaat het vooral om de kwalitatieve beoordeling van het individu, en niet zozeer om de arbeidsmarktpositie van het individu.

\subsection{4 'Employability skills' en het onderwijs}

Het hoger onderwijs is door de loop van de jaren steeds meer aandacht gaan schenken aan het ontwikkelen van 'employability' skills van studenten. In een veranderende economie waar generieke vaardigheden steeds belangrijker worden geacht, heeft het hoger onderwijs mee willen bewegen. Het hoger onderwijs kan immers beschouwd worden als hofleverancier van getalenteerde arbeidskrachten. De mate waarin opleidingen en instellingen de nadruk leggen op het bijbrengen van algemene competenties zoals communiceren, samenwerken, ICT-vaardigheden enzovoorts verschilt sterk. Hierdoor zou verondersteld kunnen worden dat de 'employability' van afgestudeerden afkomstig van opleidingen met een sterke aandacht voor die competenties kansrijker zijn op de arbeidsmarkt. Sterke empirische onderbouwing hiervoor is in deze literatuurstudie echter niet gevonden, hoewel de empirische studies vaak alleen kijken naar de kortetermijneffecten (kort na afstuderen). Ook kan geredeneerd worden dat álle opleidingen op zijn minst enige aandacht besteden aan 'employability skills'. Deze competenties kunnen immers wel degelijk waardevol zijn op de arbeidsmarkt, maar omdat alle studenten er in ieder geval iets van meekrijgen, zijn er geen duidelijke significante verschillen waarneembaar.

Wel zijn er goede aanwijzingen dat er op andere fronten binnen het curriculum winst te behalen valt. We onderscheiden hier drie empirisch onderbouwde 'employabilitybevorderende maatregelen': 
1. Bied studenten de mogelijkheid om praktijk-/werkervaring op te doen, bijvoorbeeld door externe stages op te nemen in het programma. Dit vereist goede netwerken tussen onderwijs en werkveld.

2. Betrek werkgevers bij de ontwikkeling van het curriculum én bij de daadwerkelijke uitvoering van het onderwijs, bijvoorbeeld door gastdocenten in te zetten.

3. Maak loopbaan- en arbeidsmarktoriëntatie onderdeel van het curriculum. Investeer in kennis over de arbeidsmarkt (hoe ziet de beroepenstructuur er uit, waar liggen de kansen) en over de conventies op de arbeidsmarkt (hoe dient men zich te profileren/ gedragen).

Wel moet er een slag om de arm worden gehouden. De hoeveelheid empirische literatuur naar de bijdrage van het onderwijs aan 'employability' en naar de 'waarde' van 'employability skills' is beperkt gebleken, hetgeen ook onderschreven wordt door de wetenschappers in dit vakgebied zelf. 'Employability' literatuur is vaak theoretisch van aard, waardoor uitspraken over 'effectiviteit' of 'nut' moeilijk te doen zijn. Het lijkt dan ook zinvol om het fenomeen 'employability' in de toekomst meer vanuit een empirische bril te bezien.

\subsubsection{Making the implicit explicit: 'employability' binnen de Universiteit Maastricht}

Binnen de Universiteit Maastricht is door Römgens \& Beausaert (2016) een model ontwikkelt dat, in tegenstelling tot bijvoorbeeld het USEM-model, toepasbaar is op de dagelijkse praktijk van de UM. Op basis van diverse wetenschappelijke inzichten ontwikkelden Römsgens \& Beausaert binnen het project 'Making the implicit explicit' het conceptuele kader 'UM's Employable Academic'. Met dit conceptuele kader als basis en een invulmatrix als hulpmiddel, kunnen (onder andere) opleidingen aangeven (waarom) specifieke curriculumonderdelen bijdragen aan specifieke 'employability'competenties en hoe dit gemonitord kan worden. In de basis gaat het model ervan uit dat het curriculum (tezamen met andere extracurriculaire activiteiten) bijdraagt aan verschillende typen competenties. Deze competenties zijn sterk vergelijkbaar met de verschillende competenties die in voorliggende literatuurstudie besproken zijn, zoals de verschillende 'assets' zoals Hillage \& Pollard (1998) ze onderscheiden, de 'componenten' uit het USEM-model of de 'elementen' uit het 'key to employability' model. Ook in het 'UM's Employable Academic'-model komt het op hoofdlijnen neer op dezelfde type capaciteiten. Römsgens \& Beausaert onderscheiden de competenties "academic expertise \& skills", "self-awareness", "adaptability" en "social responsibility". De ontwikkeling van deze typen competenties kunnen door opleidingen als doelstellingen worden beschouwd en het zijn deze competenties die (tezamen met persoons- en contextuele factoren) volgens het model van invloed zijn op de zelfingeschatte 'employability' en de uiteindelijke arbeidsmarktuitkomsten. 


\subsection{Discussie}

Hoewel empirisch onderzoek naar de effectieve bijdrage van het hoger onderwijs aan de 'employability' van hun studenten schaars is, bestaan er wel veel cijfers over de arbeidsmarkuitkomsten van studenten. Hierbij valt te denken aan nationale resultaten uit alumnistudies zoals de BVE-Monitor, de HBO-Monitor en de Nationale Alumni Enquête, of aan internationale rankings van universiteiten zoals in de Graduate Employability Rankings. Dergelijke cijfers geven een nuttige indicatie van verschillen tussen opleidingen en instellingen, en van ontwikkelingen over de tijd. Het is volgens Harvey (2001) echter belangrijk dat we ons hier niet blind op staren. De cijfers dienen volgens hem vooral een hulpmiddel te zijn voor opleidingen om zichzelf te evalueren en zichzelf de vraag te stellen: in hoeverre bereiden wij onze studenten goed voor op de arbeidsmarkt?

Het risico van deze cijfers, zeker als deze benut worden voor rankings, is dat ze niet meer als hulpmiddel worden beschouwd, maar als doelstelling op zich. In de meest extreme situatie zou dit er volgens Harvey toe kunnen leiden de onderwijsagenda 'gecompromitteerd' wordt, doordat instellingen bijvoorbeeld hun opleidingsaanbod gaan veranderen (niet meer, of minder aanbieden van 'minder kansrijke' opleidingen), hun toelatingsbeleid gaan versoberen (bijvoorbeeld door alleen 'topscholieren' aan te nemen) of een onevenredig grote aandacht gaan schenken aan loopbaanbegeleiding (bijvoorbeeld sollicitatietrainingen). Dergelijke ingrepen zouden het onderwijs als de grote maatschappelijke 'democratiseerder' ondermijnen.

Daarentegen is het wél belangijk dat universiteiten de 'employability'van hun studenten meer centraal stellen in hun onderwijs. De Universiteit van Maastricht is hier op verschillende manieren mee bezig. Naast het bovengenoemde project 'Making the implicit explicit', zijn er tal van initatieven die docenten en studenten meer bewust moeten maken van 'employability' en de manier waarop ze dit (binnen en buiten het curriculum) kunnen vergroten.

Hoewel uit deze literatuurstudie blijkt dat er geen kortetermijneffecten gevonden zijn voor het ontwikkelen van 'employability' skills van studenten, ontbreekt het nog aan empirische onderzoeken die een concrete invoering van een meer 'employability'gericht onderwijssysteem evalueren. Daarnaast biedt de literatuur aanwijzingen voor het vergroten van de 'employability' van studenten door middel van een hogere praktijkrelevantie in het onderwijs. Verder zijn er aanwijzingen dat opleidingen waarin het onderwijs samen met het bedrijfsleven wordt ingericht, betere perspectieven bieden voor hun studenten. Echter, ook hier geldt dat het aantal empirisch onderzochte studies beperkt is. Empirisch onderzoek naar de invoering van dergelijke maatregelen om de 'employability' van studenten te vergroten is daarom gewenst. 



\section{PROCEDURE RAADPLEGEN LITERATUUR}

De literatuur waarnaar verwezen wordt in deze rapportage is op hoofdlijnen als volgt verzameld. In de eerste fase is met behulp van zoeksystemen als Picarta en Google Scholar gezocht op enkele kerntermen als 'graduate employability', 'graduate employment', 'higher education employability', 'enhancing employability' 'employability models', enzovoorts, al dan niet in combinatie met specificerende, aanvullende termen zoals 'skills', 'empirical', 'measuring' et cetera. Deze (combinatie van) basistermen levert een overzicht van kernartikelen op die het startpunt zijn voor de tweede fase.

In de tweede fase is namelijk op basis van de referentielijsten in de betreffende artikelen gezocht naar nieuwe, relevante artikelen op het gebied van 'employability' (en hoger onderwijs). Hierdoor is een nieuwe lijst ontstaan van kernartikelen in de tweede graad (d.w.z. belangrijke bronnen die gevonden zijn vanuit eerdere bronnen). Deze procedure is voor de gevonden 'tweedegraads-artikelen' enkele keren herhaald (referenties vanuit de tweedegraads-artikelen; referenties vanuit derdegraads-artikelen enzovoorts) totdat deze bronnen weinig vernieuwende inzichten opleverden. Overigens is deze verwijzingenmethode (d.w.z. via literatuurlijsten zoeken naar nieuwe, relevante bronnen) niet alleen 'omgekeerd-chronologisch' op artikelen uitgevoerd, maar ook 'chronologisch'. Met 'omgekeerd-chronologisch' bedoelen we dat verwijzingen in literatuurlijsten per definitie ouder zijn dan het gevonden artikel zelf (immers wordt verwezen naar eerder onderzoek). Echter is het met Google Scholar ook mogelijk om 'chronologisch' te zoeken door een overzicht te tonen van jongere literatuur die verwijst naar het gevonden artikel. Deze procedure is voor de artikelen enkele keren herhaald.

Tot slot is de via deze procedure geraadpleegde literatuur aangevuld met bronnen die persoonlijk bekend zijn bij (het netwerk van) de onderzoekers. Hoewel het onmogelijk (en om het overzicht te bewaren ook onwenselijk) is om een uitputtend literatuuroverzicht te geven op het gebied van 'employability' van afgestudeerden, denken we met voorliggende rapportage een goed, algemeen beeld te geven van de bestaande wetenschappelijke inzichten op dit gebied. 



\section{REFERENTIES}

Ahmet, K. \& Fallows, S. (1999). Experiential Learning Through Practicals. In S. Fallows \& K. Ahmet (Red.), Inspiring Students: Case Studies in Motivating the Learner (7-24). London: Kogan Page.

Allen, J. \& Coenen, J. (2011). Employability and mobility of bachelor graduates in The Netherlands. In H. Schomburg \& U. Teichler (Red.), Employability and mobility of bachelor graduates in Europe (pp.171-183). Rotterdam: Springer.

Allen, J., Breugel, G. van, Coenen, J., Fouarge, D., Meng, C., Ramaekers, G., Dijk, J. van \& Venhorst, V. (2009). Afgestudeerden van het hbo tijdens een crisis: geen verloren generatie. Den Haag: HBOraad.

Andrews, J., \& Higson, H. (2008). Graduate Employability, 'Soft Skills' Versus 'Hard' Business Knowledge: A European study. Higher education in Europe, 33(4), 411-422.

Bakar, A., \& Hanafi, I. (2007). Assessing employability skills of technical-vocational students in Malaysia. Journal of Social Sciences, 3(4), 202-207.

Baillie, L. (1998). Problem based learning in nurse education. HELP! Higher Education: Learning and Practice, 3.

Bandura, A. (1995). Exercise of personal and collective efficacy in changing societies. In A. Bandura (Red.), Self-Efficacy in Changing Societies (pp.1-45). Cambridge: University Press.

Bennett, N., Dunne, E. \& Carré, C. (1999). Patterns of core and generic skill provision in higher education. Higher education, 37(1), 71-93.

Blasko, Z., Brennan, J. \& Shah, T. (2003). Access to What: Analysis of Factors Determining Graduate Employability. Bristol: Higher Education Funding Council England.

Borghans, A., Fouarge, D., Grip, A. de, \& Thor, J. van (2014). Werken en leren in Nederland. Maastricht: Researchcentrum voor Onderwijs en Arbeidsmarkt.

Bridgstock, R. (2009). The graduate attributes we've overlooked: Enhancing graduate employability through career management skills. Higher Education Research \& Development, 28(1), 31-44.

Brown, P., Hesketh, A., \& Wiliams, S. (2003). Employability in a knowledge-driven economy. Journal of education and work, 16(2), 107-126.

Cappelli, P. (1995). Is the "Skills Gap" Really About Attitudes? California Management Review, 37(4), 108-124.

Cooper, R. (1997). Applying emotional intelligence in the workplace. Training \& Development, 51(12), 31-39.

Cranmer, S. (2006). Enhancing graduate employability: best intentions and mixed outcomes. Studies in Higher Education, 31(2), 169-184.

Dacre Pool, L., \& Sewell, P. (2007). The key to employability: developing a practical model of graduate 
employability. Education + Training, 49(4), 277-289.

Fallows, S., \& Steven, C. (2000). Building employability skills into the higher education curriculum: A university-wide initiative. Education + training, 42(2), 75-83.

Feinstein, L. (2000). The Relative Economic Importance of Academic, Psychological and Behavioural Attributes Developed in Childhood. London: Centre for Economic Performance.

Felstead, A., Gallie, D., Green, F., \& Zhou, Y. (2007). Skills at Work in Britain, 1986 to 2006. Oxford/ Cardiff: ESRC Centre on Skills, Knowledge and Organisational Performance.

Firpo, S., Carvalho, S., \& Pieri, R. (2016). Using occupational structure to measure employability with an application to the Brazilian labor market. Journal of Economic Inequality, 14(1), 1-19.

Forrier, A., \& Sels, L. (2005). Het concept employability: Een puzzel met veel stukjes. Tijdschrift voor $H R M, 8(3), 47-73$.

Fugate, M. (2006). Employability. In J. Greenhaus \& G. Callanan (Red.), Encyclopedia of career development (pp.267-271). Thousand Oaks: Sage.

Fugate, M., \& Kinicki, A. (2008). A dispositional approach to employability: Development of a measure and test of implications for employee reactions to organizational change. Journal of Occupational and Organizational Psychology, 81(3), 503-527.

Ganzeboom, H. (1997). Onderwijsexpansie en onderwijskansen. In H. Ganzeboom \& W. Ultee (Red.), De sociale segmentatie van Nederland in 2015 (pp.13-48). Den Haag: Sdu Uitgevers.

Goleman, D. (1998). Working with emotional intelligence. London: Bloomsbury.

Hager, P., Holland, S. and Beckett, D. (2002). Enhancing the Learning and Employability of Graduates: The Role of Generic Skills. Business/HigherEducation Round Table Position Paper No. 9. Melbourne, Australia.

Harvey, L. (1999). Employability Audit Toolkit. Birmingham: Centre for Research into Quality.

Harvey, L. (2000). An employability performance indicator. Perspectives: Policy \& Practice in Higher Education, 4(4), 105-109.

Harvey, L. (2001). Defining and measuring employability. Quality in higher education, 7(2), 97-109.

Hesketh, A. (2000). Recruiting an elite? Employers' perceptions of graduate education and training. Journal of education and work, 13(3), 245-271.

Hillage, J. \& Pollard, E. (1998). Employability: Developing a Framework for Policy Analysis. London: DfEE.

Hughes, I. \& Macfarlane-Dick, D. (z.j). Employability audits and change in the curriculum. Gevonden op 20 januari 2017 op: http://www.enhancementthemes.ac.uk/docs/workshop/employabilityaudits-and-change-in-the-curriculum.pdf.

Jackson, D. (2010). An international profile of industry-relevant competencies and skill gaps in modern graduates. International Journal of Management Education, 8(3), 29-58.

Jackson, D. (2013). Student perceptions of the importance of employability skill provision in business undergraduate programs. Journal of Education for Business, 88(5), 271-279.

Keep, E., \& Mayhew, K. (2004). The economic and distributional implications of current policies on higher education. Oxford Review of Economic Policy, 20(2), 298-314.

Knight, P., \& Yorke, M. (2002). Employability through the curriculum. Tertiary education and management, 8(4), 261-276.

Knight, P \& Yorke, M (2004). Learning, Curriculum and Employability in Higher Education. London: RoutledgeFalmer.

Law, W. \& Watts, A. (1977). Schools, Careers and Community. London: Church Information Office. 
Lees, D. (2002). Graduate employability-literature review. York: LTSN Generic Centre.

Light, A. (2001). In-school work experience and the returns to schooling. Journal of Labor Economics, 19(1), 65-93.

Lim, H. (2010). Predicting low employability graduates: The case of Universiti Utara Malaysia. The Singapore Economic Review, 55(3), 523-535.

Little, B. (2003). International perspectives on employability. Briefing Paper. York: The Higher Education Academy.

Marmaros, D., \& Sacerdote, B. (2002). Peer and social networks in job search. European economic review, 46(4), 870-879.

Mason, G., Williams, G., \& Cranmer, S. (2009). Employability skills initiatives in higher education: what effects do they have on graduate labour market outcomes? Education Economics, 17(1), 1-30.

McGuinness, S. (2003). University quality and labour market outcomes. Applied Economics, 35(18), 1943-1955.

Moon, J. (2004), Reflection and Employability. York: The Higher Education Academy.

Norman, M., \& Hyland, T. (2003). The role of confidence in lifelong learning. Educational studies, 29(23), 261-272.

NVAO (2004). Dublin Descriptoren. Gevonden op 20 januari 2017 op: https://www.nvao.net/system/ files/pdf/Dublin\%20Descriptoren.pdf.

Okay-Somerville, B., \& Scholarios, D. (2015). Position, possession or process? Understanding objective and subjective employability during university-to-work transitions. Studies in higher education, 1-17.

Owens, T. (1993). Accentuate the Positive - and the Negative: Rethinking the use of self-esteem, self-deprication, and self-confidence. Social Psychology Quarterly, 56(4), 288-299.

Pegg, A., Waldock, J., Hendy-Isaac, S. \& Lawton, R. (2012). Pedagogy for employability. York: Higher Education Academy.

Purcell, K. \& Pitcher, J. (1996). Great Expectations: The New Diversity of Graduate Skills and Aspirations. Manchester: CSU.

Römgens, I. \& Beausaert, S. (2016). The Employability Scanner. Identifying and strengthening the development of employability competencies in UM curricula.

Salter, B. \& Tapper, T. (1994). The State and Higher Education. Ilford: Woburn Press.

Saterfiel, T. \& McLarty, J. (1995). Assessing employability skills. Greensboro: ERIC Clearinghouse on Counseling and Student Services.

Smith, C., Ferns, S., \& Russell, L. (2014). Conceptualising and measuring 'employability' - lessons from a National OLT Project. ACEN National Conference, Tweed Heads.

Smith, J., McKnight, A., \& Naylor, R. (2000). Graduate employability: policy and performance in higher education in the UK. The Economic Journal, 110(464), 382-411.

Steinem, G. (1992). Revolution from Within: A Book of Self-Esteem. Boston: Little Brown \& Company.

Thomas, V., Wang, Y. \& Fan, X. (2001). Measuring education inequality: Gini coefficients of education. Washington: World Bank Publications.

Thompson, P. (2004). Skating on thin ice: the knowledge economy myth. Glasgow: University of Strathclyde.

Tolsma, J. \& Wolbers, M. (2010). Onderwijs als nieuwe sociale scheidslijn? Tijdschrift voor Sociologie, 3(4), 239-259.

Tucker, M., Sojka, J., Barone, F., \& McCarthy, A. (2000). Training tomorrow's leaders: Enhancing the 
emotional intelligence of business graduates. Journal of Education for Business, 75(6), 331-337. VSNU (2016). Academici op de arbeidsmarkt. Den Haag: VSNU.

Watts, A. (2006). Career development learning and employability. York: The Higher Education Academy.

Werbel, J. D. (2000). Relationships among career exploration, job search intensity, and job search effectiveness in graduating college students. Journal of Vocational Behavior, 57(3), 379-394.

Wilton, N. (2011). Do employability skills really matter in the UK graduate labour market? The case of business and management graduates. Work, employment and society, 25(1), 85-100.

Yorke, M. (2006). Employability in higher education: What it is what it is not. In M. Yorke (Red.), Learning and employability. New York: Learning and Teaching Support Network. 